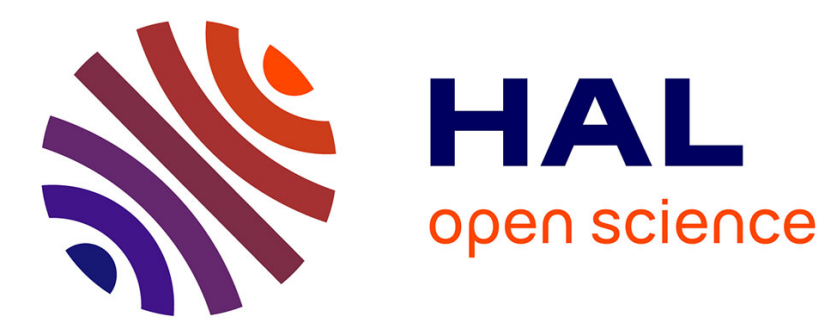

\title{
Hotspots of relative sea level rise in the Tropics
}

Melanie Becker, Mikhail Karpytchev, Fabrice Papa

\section{To cite this version:}

Melanie Becker, Mikhail Karpytchev, Fabrice Papa. Hotspots of relative sea level rise in the Tropics. Tropical Extremes: Natural Variability and Trends, Elsevier, pp.203-262, 2019, 978-0-12-809248-4. 10.1016/B978-0-12-809248-4.00007-8 . hal-01773784

\section{HAL Id: hal-01773784 https://hal.science/hal-01773784}

Submitted on 14 Sep 2018

HAL is a multi-disciplinary open access archive for the deposit and dissemination of scientific research documents, whether they are published or not. The documents may come from teaching and research institutions in France or abroad, or from public or private research centers.
L'archive ouverte pluridisciplinaire HAL, est destinée au dépôt et à la diffusion de documents scientifiques de niveau recherche, publiés ou non, émanant des établissements d'enseignement et de recherche français ou étrangers, des laboratoires publics ou privés. 
Preprint of: Becker, M., Karpytchev, M., \& Papa, F. (2018). Hotspots of relative sea level rise in the Tropics. In Tropical Extremes: Natural Variability and Trends (pp. 203-251). Elsevier. Retrieved from www.elsevier.com/books/tropical-extremes-natural-

variability-and-trends/vuruputur/978-0-12-809248-4

\section{Chapter 4: Hotspots of relative sea level rise in the Tropics}

M. Becker ${ }^{1, *}$, M. Karpytchev ${ }^{1}$ and F. Papa ${ }^{2,3}$

${ }^{1}$ LIENSs/CNRS, UMR 7266, ULR/CNRS, 2 rue Olympe de Gouges, La Rochelle, France ${ }^{2}$ LEGOS/IRD, UMR 5566, CNES/CNRS/IRD/UPS, 14 Avenue Edouard Belin, Toulouse, France

${ }^{3}$ Indo-French Cell for Water Sciences, IRD-IISc-NIO-IITM, Indian Institute of Science, Bangalore, India

${ }^{*}$ Corresponding authors: melanie.becker@univ-lr.fr

\section{Abstract}

This chapter presents changes in relative sea level (RSL) along tropical coastlines $\left(30^{\circ} \mathrm{N}-30^{\circ} \mathrm{S}\right)$.

Under current and future global changes, $90 \%$ of the coastlines are at risk, facing challenges of rising sea level (SL). Since the last century, scientists have attempted to understand processes governing RSL, to separate variations in absolute SL from those due to vertical land movement, and to discover their links to climate change. Recently developed space technologies provide accurate estimates of ongoing SL changes. Combined with tide gauge records, these new 8 instruments (GPS, altimetry, InSAR) offer a new perspective for the science associated with 9 sea level and its changes. This chapter reviews the concept of RSL, of RSL hotspots and 0 describes different RSL measurements. Then, it identifies and maps the hotspots of RSL 1 changes and updates, where possible, previously published estimates of RSL trends. 2 Identification of the RSL hotspots is of paramount importance for climate change mitigation 3 and adaptation in tropical regions.

Keywords: relative sea level ; tide gauge ; Tropics ; GPS ; altimetry ; land movement; delta 
Preprint of: Becker, M., Karpytchev, M., \& Papa, F. (2018). Hotspots of relative sea level rise in the Tropics. In Tropical Extremes Natural Variability and Trends (pp. 203-251). Elsevier. Retrieved from www.elsevier.com/books/tropical-extremes-natural-

variability-and-trends/vuruputur/978-0-12-809248-4

\subsection{Introduction}

The pronounced impact of climate change on natural systems and human societies is a reality. Understanding the extent to which people, societies, ecosystems and economy are exposed to risk under current and future climate is a challenging issue for modern science. One of the major consequences of the ongoing climate change is a rise in sea level (SL). The Intergovernmental Panel on Climate Change reported [IPCC AR5, 2013] that the global mean sea level (GMSL, 1.6 to $1.8 \mathrm{~mm} / \mathrm{yr}$ rise over the $20^{\text {th }}$ century [Church et al., 2013]) will continue rising in the $21^{\text {st }}$ century and beyond, at probably a faster rate than observed today, even if the global temperature will be stabilized. Almost $90 \%$ of the coastlines worldwide will face challenges of rising sea level [IPCC AR5, 2013] although to different extent as the rates of the sea level rise can be several times larger in some regions than the GMSL rise [Church et al., 2013]. Consequently, the part of coastal vulnerability reflecting a high and growing exposure and low adaptive capacity of the coastal populations to sea level rise is not spatially uniform either [Nicholls et al., 2011]. Certain regions throughout the world, especially in developing countries, are already recognized as particularly vulnerable to sea level rise; for example, small islands in the Caribbean Sea, Maldives Archipelago in the Indian Ocean, Tuvalu Islands in the Pacific, or the West African coast from Morocco to Namibia, the south Asian coast from Pakistan to Burma as well as the coasts in southeast Asia from Thailand to Vietnam [Nicholls et al., 1999; Nicholls and Cazenave, 2010]. Nicholls et al., [2011] defined these specific regions as areas where an efficient protection against sea level rise will most likely fail, potentially resulting in a significant portion of environmental refugees. It is worth mentioning here that those cases are related to relative sea level (RSL) changes, which are felt by coastal populations, i.e. the changes in sea level relative to the land on which people live. Focusing on the analysis of the RSL variations is of obvious practical importance, since it makes little difference to a person nearly submerged, whether the ocean is rising or land is subsiding [Milliman and Haq, 1996]. Pronounced dispersion in the rates of RSL rise calls for detailed investigation of the processes responsible for sea level changes not only at the global scale but also at the regional scale. The RSL changes are induced by a combination of various processes of a different nature and operating at different spatial and temporal scales, originated in the ocean, ice, atmosphere, sediment transport, and the solid Earth deformation inducing land subsidence or uplift [Stammer et al., 2013]. Ocean temperature and salinity variations resulting from water heating, precipitation or freshwater discharge from land can contribute to regional sea level fluctuations by changing the sea water density. Additional freshwater fluxes from river discharge or land 
ice melting modify ocean currents, which in turn also have significant repercussions on regional sea level variations [Stammer, 2008], with signals taking decades to propagate around the global ocean. Atmospheric pressure, at different scales, also plays a role in regional sea level variations [Ponte, 1994; Wunsch and Stammer, 1997; Piecuch and Ponte, 2015]. Concerning the vertical land movements, there exists a wide range of natural and anthropogenic processes, which can induce them. The water mass exchanges between land and ocean lead to changes in the Earth's surface and in the geoid that manifest themselves as part of observed RSL variations [Milne et al., 2009; Stammer et al., 2013]. These result from different processes: (1) ice-water mass redistribution associated with ice cap melting since the Last Glacial Maximum (called post glacial rebound or Glacial Isostatic Adjustment/GIA; [Peltier, 2004; Lambeck et al., 2010]), (2) ongoing land ice melting [Mitrovica et al., 2001; Tamisiea and Mitrovica, 2011] and (3) land water storage variation [Riva et al., 2010]. GIA involves the visco-elastic response of the Earth's mantle to mass redistribution, while processes (2) and (3) involve the elastic response of the Earth's crust. GIA and present-day mass redistributions produce very different response of the solid Earth, and thus regional RSL variations (see, for example, [Milne et al., 2009; Tamisiea, 2011; Tamisiea and Mitrovica, 2011]). We now call these processes 'static' effects (e.g.,[Stammer et al., 2013]). The solid Earth also responds to sediment loading, referred to herein as sedimentary isostatic adjustment, that often induces strong subsidence within the deltas [Blum and Roberts, 2009; Syvitski et al., 2009]. Many other natural processes, such as tectonics and volcanism, can also generate land movements that are more local when compared to the 'static' effects discussed above. Aside from most of these natural factors, an additional complex dimension to these changes is the non-negligible impact of human activities; For instance, sea level can be modified through building of dams and reservoirs, irrigation and hydrocarbon extraction, groundwater pumping among many other processes [Fiedler and Conrad, 2010; Wada et al., 2012, 2016]. These anthropogenic forcings affect directly the land water storage, and hence water mass exchange between land and ocean [Milly et al., 2010] and consequently can generate locally significant vertical land movement. Several Asian megacities subsided by several meters during the past few decades owing to groundwater withdrawal or hydrocarbon extraction [Syvitski, 2008].

In this chapter, we focus on the RSL changes within the Tropics, defined below as a region from $30^{\circ} \mathrm{N}$ to $30^{\circ} \mathrm{S}$ latitude. The Tropics are home to $40 \%$ of the world's population, and this proportion is projected to reach $50 \%$ by 2050 [Edelman et al., 2014]. From today until 2050, 
the largest coastal population growth is expected to take place in Africa where the population

will double [Edelman et al., 2014]. Assessing the vulnerability of tropical coasts to future climate change and elaborating an efficient climate mitigation policy is one of the most important global issues of our time. Developing countries that make up a majority of tropical regions are the most vulnerable to RSL changes, because they have limited resources to adapt themselves socially, technologically and financially. Moreover, it is important to note that the Tropics host the largest deltas in the world. These low-lying delta plains are crucially affected by land subsidence that often makes the sea along the delta coasts to rise much faster than the GMSL rises. As the deltas are a home to tens of millions of people, the densely populated deltaic environments become a suitable site for springing up of megacities (greater than 5 million inhabitants) with the associated complex problems of their management.

One of the objectives of this chapter is to bring together sea level observations in order to analyze similarities and differences in the RSL changes along the tropical coasts. It is crucial for all evaluations of coastal impacts, vulnerability, and adaptation, to account for the RSL rise, especially along the low-lying populated coasts where RSL is rising much faster than its global average rate. We call these sites hotspots of RSL rise [Sallenger et al. 2012]. Our primary concern is to review the current knowledge about RSL in the tropical regions and to: (1) comprehensively identify, document and map the hotspots of RSL changes; (2) give an overview of available long-term sea level records, and (3) update, where possible, previously published estimates of RSL trends over recent decades. Section 2 will review the different datasets currently available to study RSL. Then we will dedicate a specific section for each of the Oceans in the tropical band, with a sub-section dedicated to large oceanic sub-basins. For each region, we will document both the societal and physical aspects of RSL. At the end of each section, we summarize the main features of the respective RSL hotspots.

\subsection{Data sets}

\subsubsection{Tide gauge records}

126 Tide gauge (TG) records are the main source of information available to assess coastal sea level 127 changes since the mid- $19^{\text {th }}$ century. The TGs were designed to measure RSL, namely, the water 128 level relative to land on which they are installed [Pugh and Woodworth, 2014]. Therefore, the 129 TG measurements reflect absolute sea level (ASL, i.e. in respect to the center of the Earth) 130 changes but also local vertical land movements along with changes in the geoid. The worldwide 
geographical distribution of TGs is particularly limited and irregular with an obvious lack of stations in the Southern Hemisphere, particularly in developing countries and island states. In our analyses, we use annually averaged sea level series from the Permanent Service for Mean Sea Level (PSMSL) Revised Local Reference (RLR) database [Holgate et al., 2013]. The PSMSL recommends using the RLR records, where the sea level means were reduced to a common datum, for time series analysis. The PSMSL also provides the 'Metric' data, without datum continuity checked and with, sometimes, large discontinuities. These metric records should only be used in studies pertaining to the seasonal cycle of mean sea level [Holgate et al., 2013]. The length of TG records, as well as the number of missing values, are of crucial importance for estimating long-term trends. Douglas, [2001] has concluded that more than 5060 years of continuous measurements are required for a long-term sea level trend to be reliably estimated. In this study, we reduce this constraint by estimating trends at the stations with records longer than 30 years, and with less than 4 consecutive years of missing data.

\subsubsection{Satellite altimetry}

Since 1993, satellite altimetry has been used for measuring spatial and temporal variations of absolute sea level (hereafter, called ASL) rise. The ASL products, consisting of sea surface heights, are routinely processed and distributed by six groups: Archiving, Validation and Interpretation of Satellite Oceanographic data (AVISO), Commonwealth Scientific and Industrial Research Organization (CSIRO), Colorado University (CU), Goddard Space Flight Center (GSFC), European Space Agency Climate Change Initiative (ESA-CCI) and Delft University of Technology (TUDelft-RADS). Here, we chose to use the newly reprocessed ESACCI Sea Level v1.1 gridded altimetry product (hereafter, called ESA) that is freely available at: http://www.esa-sealevel-cci.org (see details in Ablain et al., [2015]). In order to remove the seasonal signal in the ASL time series, we used a 12-month running mean filter.

\subsubsection{Reconstruction of sea level in the past}

Recently, a new approach was developed to reconstruct the ASL variations in the past. This method combines information from TG records with spatial patterns from altimetry and/or oceanic models [Church et al., 2004; Llovel et al., 2009; Hamlington et al., 2011; Ray and

161 Douglas, 2011; Meyssignac et al., 2012a]. In order to get an overview of the regional ASL

162 variation in the Tropics over a longer period, we employ an updated version of past sea level 163 reconstruction developed by Meyssignac et al., [2012a] for the period 1960-2014. This method 
Preprint of: Becker, M., Karpytchev, M., \& Papa, F. (2018). Hotspots of relative sea level rise in the Tropics. In Tropical Extremes: Natural Variability and Trends (pp. 203-251). Elsevier. Retrieved from www.elsevier.com/books/tropical-extremes-natural-

variability-and-trends/vuruputur/978-0-12-809248-4

164 is based on reduced optimal interpolation, combining long-term TG records with a time varying 165 linear combination of Empirical Orthogonal Functions-based spatial patterns derived from 2-D 166 sea level grids based on oceanic model outputs.

\subsubsection{GPS stations}

169 The Global Positioning System (GPS) is used for precisely positioning TG benchmarks with respect to the center of mass. These measurements, due to their relatively low cost and easy implementation, and maintenance, have become key components for sea level studies as they

172 provide accurate determination of coastal vertical land movements [Wöppelmann et al., 2007;

173 Wöppelmann and Marcos, 2016]. In this study, we use vertical velocities estimated by the 174 University of La Rochelle from its latest GPS data reanalysis (called hereafter ULR6, 175 [Santamaría-Gómez et al. 2017]). These estimates are made at the GPS stations that are directly collocated with TGs or situated not further than $15 \mathrm{~km}$ from them, provided that the GPS series have more than 3 years of data [Wöppelmann et al., 2007]. The magnitudes of vertical velocity and their associated uncertainties are available (free of cost) at http://www.sonel.org; the GPS at tide gauge data assembly center Système d'Observation du Niveau des Eaux Littorales (SONEL).

\subsubsection{Urban agglomerations and Low Elevation Coastal Zones (LECZ)}

We used the Urban-Rural Population and Land Area Estimates v2 dataset, providing the number of people living on contiguous coastal elevations less than or equal to $10 \mathrm{~m}$ in 2010 . This dataset is from the Low Elevation Coastal Zone collection (LECZ, [McGranahan et al., 2007]) and is freely downloadable from http://sedac.ciesin.columbia.edu/data/ collection/lecz.

\subsection{Atlantic Ocean}

\subsection{1. $\quad$ Eastern South America}

The Tropical Atlantic Ocean is bordered in the west by the Brazilian coast extending through

191 the Caribbean Sea to the Gulf of Mexico. The entire Brazilian coastline, extending from latitude $4^{\circ} \mathrm{N}$ to $34^{\circ} \mathrm{S}$, has been experiencing erosion, although the erosion rates vary irregularly and are often enhanced within river outlets [Muehe, 2010]. Since 1970s, rapid expansion of 
Brazilians live in coastal cities [Muehe and Neves, 1995] (Figure 4.1). For example, the population density of the megacity of Rio de Janeiro has nearly doubled in four decades (27 inhab/ha in 1960 to 48 inhab/ha in 2000, [Saglio-Yatzimirsky 2013]); presently, its population exceeds 12 million people. In the Northeast, Recife is a large metropolitan city with approximately 4 million inhabitants that ranks among the cities in Brazil, with the highest population density at the coast [Muehe and Neves 1995; Neves and Muehe 1995]. This city is located at the mouth of two rivers, Beberibe and Capibaribe, within low-lying areas making it particularly vulnerable to RSL rise. All these large coastal cities, where the problems of urban drainage are nowadays permanent, have to deal with floods. In 2008 , around $30 \%$ of more than 5.5 thousand municipalities in Brazil reported having inefficient drainage system and having suffered from floods in the past five years [Nali and Rigo 2011]. The consequences of drainage system deficiency in urban areas are important, ranging from impacts on human health, through groundwater contamination and proliferation of mosquitoes, to damage effects, inter alia, on housing, infrastructure and psychological stress. These effects will become even more critical with a rise in RSL [Muehe 2010].

211 In the north, the Brazil coastline of the Amazon Delta extends from Cape Orange in the state 212 of Amapa up to the French Guiana's border. Despite deforestation, dam construction and land 213 usage, the delta is in relatively good health [Syvitski et al. 2009]. Mansur et al. [2016] estimated 214 that over 1.2 million people are under the risk of flooding (fluvial and coastal) in this delta, and that $41 \%$ of urban sector inhabitants are exposed to potential flooding risks. The population of the Amazon Delta is projected to grow by more than $60 \%$ over the 15 -year period [Overeem and Syvitski, 2009], making this region particularly vulnerable to anthropogenic changes. The Orinoco Delta in Venezuela is an area with small population and is less developed. However, it is estimated that by $2050,21 \%$ of this delta population will be potentially inundated due to future RSL rise and $20 \%$ of the delta area could be lost [Ericson et al. 2006].

221 Over the last few decades, the observed retreat of mangrove vegetation along the delta coastline seems to be compatible with a long-term relative sea-level rise trend [Cohen and Lara 2003;

223 França et al. 2012]. Gratiot et al. [2008] have shown that the mangrove retreat of the $1500 \mathrm{~km}$ 224 long flat muddy coast from the Amazon to the Orinoco (Venezuela) rivers over the last twenty 225 years has been governed primarily by the lunar 18.6-year low-frequency tide constituent. These 226 findings highlight an extreme sensitivity of this region to global environmental changes in 227 general, and, in particular, to sea level changes. 
Preprint of: Becker, M., Karpytchev, M., \& Papa, F. (2018). Hotspots of relative sea level rise in the Tropics. In Tropical Extremes Natural Variability and Trends (pp. 203-251). Elsevier. Retrieved from www.elsevier.com/books/tropical-extremes-natural-

variability-and-trends/vuruputur/978-0-12-809248-4

228 Populations of the northern Brazil neighboring countries will also face sea level rise adaptation problems: thus, in terms of population impacted by a $1 \mathrm{~m}$ sea level rise, at least $6 \%$ of people

230 living in Guyana, Suriname and French Guiana population would be displaced [Dasgupta et al. 231 2009]. These countries are among the top 10 countries/territories worldwide affected by 232 climate-induced massive population relocation.

233 From the PSMSL RLR data set, 11 TG records are available along the Brazilian coast and one 234 recent record from French Guiana (Ile Royale, 10 years, 2006-2015). Of these sea level records, 235 only two from southeastern Brazil cover recent years and are long enough to allow long-term 236 trend estimates: Cananeia (53 years, 1954-2006) and Rio de Janeiro (Ilha Fiscal station: 51 237 years, 1963-2013). The length of the other records is less than 21 years. Emery and Aubrey 238 [1991] reviewed all records from Brazil available at PSMSL and noted a coherent RSL rise of 239 about 2-4 mm/yr between 1950 and 1970; this was interpreted as land subsidence except for 240 RSL observations at Recife, Belem and Imbituba, where the trends are close to zero. The lower trends were suggested to result from land movement produced at Recife by the Pernambuco fault, and to sediment-induced subsidence at Imbituba and Belem. More recent work has revisited these long-term trends and estimated RSL trend in the range 3-5 mm/yr over the past 50 years [Neves and Muehe 1995; Mesquita 2003; Muehe 2006; Mesquita et al. 2013]. We searched for new records in PSMSL to update the Emery and Aubrey results, but have found only two recent series: One at Cananeia and another at Ihla Fiscal (Table 4.1). The Ilha Fiscal record exhibits no significant RSL trend over 1967-2013, the signal being dominated by strong multidecadal fluctuations. The presence of the multidecadal sea level signal explains the low statistical confidence of the trend estimate at Ihla Fiscal noticed by Emery and Aubrey (1991). Our estimate of the RSL trend at Cananeia over a 50-year span (Table 4.1) is of 4.1 $\mathrm{mm} / \mathrm{yr}$ (Table 4.1) that is surprisingly coherent with $4.2 \mathrm{~mm} / \mathrm{yr}$ obtained by Emery and Aubrey over the first 30 years of apparently the same sea level record. A different trend was found, however, by Ducarme et al. [2007] who estimated a larger RSL trend of $5.6 \pm 0.07 \mathrm{~mm} / \mathrm{year}$ after having identified and corrected two periodicities of 24.2 year and 10.7 year dominating the very low frequency spectrum of sea level at Cananeia. This rate, over the last 50 years, largely exceeds the observed GMSL trend from satellite altimetry over the last 22 years (3.1 to $3.3 \mathrm{~mm} / \mathrm{yr}$, [Cazenave and Le Cozannet 2013]) and Cananeia should be classed as a strong positive anomaly, a hotspot, in the global sea level rise pattern [Mesquita et al. 2013]. The reasons of the increased rate of RSL rise at Cananeia have not been completely explained yet, 260 but they are unlikely due to land subsidence alone. (It is worth noting here that Aubrey et al. 
[1988], Muehe and Neves [1995] and Mesquita et al. [2013] previously presented evidence that the Brazilian coast may be sinking.) An apparent contradiction comes from the NEIA GPS station collocated (Table 4.1) with the Cananeia TG (10 $\mathrm{m}$ distance from the tide-gauge and 15 years in operation). Indeed, no significant trend in vertical movement was detected by the NEIA GPS at the Cananeia TG over the last 15 years (Table 4.1). Yet, it does not exclude an increased RSL rise at Cananeia, as it can also be due to oceanic processes. Notice, however, that the ASL absolute sea level trends near Cananeia vary between 1.8 and 3 mm/yr over 1993-2014 similarly to the sea level trends of about $2.5 \mathrm{~mm} / \mathrm{yr}$ reconstructed near the Brazilian coast over 19602014 (Figure 4.4).

The other two GPS stations on the Brazilian coast are collocated with Recife and Imbituba TG, the two sites likely influenced by local land movement [Emery and Aubrey 1991]. Land subsidence of $2.4 \mathrm{~mm} / \mathrm{yr}$ is observed at RECF GPS, at $9 \mathrm{~km}$ from the Recife TG, and slower subsidence of $1.1 \mathrm{~mm} / \mathrm{yr}$ at IMBT GPS, 700m from Imbituba TG. Unfortunately, the lack of modern TG records at Recife and Imbituba does not allow separating the contribution of land movement from oceanic component in the observed RSL. The lack of data and insufficient density of the TG network is a major obstacle for accurate evaluation of regional sea level changes in this region. Since 2007, efforts are being made to implement a Permanent Brazilian Sea Level Monitoring Network called Global Sea Level Observing System (GLOSS)-Brazil Network. Under this program, twelve new TG stations have been installed and are now fully operational (data available on http://www.goosbrasil.org/gloss). This gives hope for obtaining more precise and accurate long-term sea-level measurements along the coast of Brazil [Lemos and Ghisolfi 2011].

\subsubsection{Caribbean Sea}

284 The Caribbean Sea is bounded in the west by Central America and, in the south, by Venezuela and Colombia. It is connected to the Gulf of Mexico through the Yucatan straits in the north. Cuba, the Greater Antilles and the Lesser Antilles, separate the Caribbean Sea from the Atlantic Ocean to the north and northeast. The Caribbean Sea includes more than 7000 islands that are particularly vulnerable to sea level rise because of high population density. Indeed, about half of the island population lives within $1.5 \mathrm{~km}$ from the sea [Mimura et al. 2007] because of its dependence on coastal and sea resources [Nicholls and Cazenave 2010]. Dasgupta et al. [2009] identified, among 84 coastal developing countries, the Bahamas is one of the 5 most impacted 
countries of 1-meter SL rise. In terms of potential land loss, Belize, Puerto Rico, Cuba and Jamaica are ranked in the top 10 in the sea level vulnerability classification (from 1 to $2 \%$ of loss, Dasgupta et al. 2009). Similarly, Jamaica and Belize are among the top 5 in the classification of the largest wetland loss triggered by sea level rise ( $\sim 30 \%$ of loss, Dasgupta et al. 2009). Moreover, the unique biodiversity of the Caribbean Sea islands [Mittermeier et al. 2011] appears to be particularly threatened by the projected sea level rise. With a 1-m of sea level increase, $\sim 9 \%$ of the islands (i.e. 63 islands among the 723 identified as biodiversity hotspot by Bellard et al. 2014) is expected to be entirely submerged, and the worst-case scenario of a 6-m increase would lead to a loss of half of the islands (i.e. 356 islands).

Updating Palanisamy's et al. [2012] work, over the 1960-2014 reconstruction period, we observed strong positive ASL trends in the Caribbean of about 2.5-3 mm/yr (Figure 4.4), except for Cuba, the Lesser and Greater Antilles where the ASL trends are lower, at around 1.8-2.5 $\mathrm{mm} / \mathrm{yr}$ (Figure 4.4). The RLR TG records from the PSMSL dataset corroborate these findings. Only seven sea level records span more than 30 years (Table 4.2). Two stations are located on the continent: Cartagena (1949-1992, 44yr) in Colombia shows an RSL trend of $5.2 \mathrm{~mm} / \mathrm{yr}$, and Cristobal (1909-1979, 71yr) in Panama shows an RSL trend of $1.5 \mathrm{~mm} / \mathrm{yr}$. The former trend is the fastest of the long-term Caribbean sea level observations (Figure 4.2) that places Cartagena among the cities directly threatened by rising sea level. The RSL measurements along the Antilles chain reveal trends of: i) about $3 \mathrm{~mm} / \mathrm{yr}$ in the Virgin Islands; and ii) about $2 \mathrm{~mm} / \mathrm{yr}$ in Puerto Rico and Cuba. Over the 1993-2014 altimetry period, we observe strong positive ASL trends from Nicaragua, southward through Venezuela to the Lesser Antilles, in the range of 3-

$3135 \mathrm{~mm} / \mathrm{yr}$ (Figure 4.3), which is greater than the GMSL trend over the same period. In the eastern 314 part of the Caribbean Sea, the ASL trends are smaller; they range from 1.8 to $3 \mathrm{~mm} / \mathrm{yr}$ (Figure 315 4.3) along the Greater Antilles islands, in particular along the coasts of Cuba, Jamaica, Haiti 316 and Puerto Rico. It is worth noting here that the seismically active Lesser Antilles subduction 317 zone is a potential source of tsunami-induced flooding all along the Caribbean coasts [McCann $3182006]$.

319 GPS stations (Table 4.2) are concentrated in the US Virgin Islands with the only station available on the continental coast, at Cartagena. All GPS records span about 9 years, except the station in Lime Tree Bay where the record is for 21 years. Analysis of the GPS data at Cartagena reveals a trend of $1.7 \mathrm{~mm} / \mathrm{yr}$ that is most likely due to land movement along the fault [Emery and Aubrey 1991]. In this case, the ocean contribution to the $5.2 \mathrm{~mm} / \mathrm{yr}$ RSL trend at Cartagena 
would be about $3.5 \mathrm{~mm} / \mathrm{yr}$. It is difficult to answer whether the 9-year long GPS series are long enough for estimating land movement in these regions. In order to get an insight into this issue, we compared the trends derived from two GPS stations in Lime Tree Bay. The 21-year long CR01 GPS station shows a trend of $2.9 \mathrm{~mm} / \mathrm{yr}$ while another one, which has a 9-year long record, has a much smaller trend of $1.1 \mathrm{~mm} / \mathrm{yr}$. This points out to a possible non-stationary character or significant spatial variation in vertical land movements in Lime Tree Bay.

Along the Bahamas Islands, the ASL trends range from 0 to $3 \mathrm{~mm} / \mathrm{yr}$, but some trends in this region are statistically insignificant, and some have high uncertainty (Figure 4.3) due to pronounced interannual sea level variability in the Caribbean region. Torres and Tsimplis

Along the U.S. Gulf coast, the population grew up $150 \%$ and housing construction by $246 \%$ [2013] show that the interannual fluctuations in this region can be partly explained by the influence of El Niño-Southern Oscillation (ENSO) at different time and space scales; however, they found no significant link with the North Atlantic Oscillation (NAO).

\subsubsection{Gulf of Mexico} from 1960 to 2008 [Wilson and Fischetti 2010]. In August 2005, hurricane Katrina (followed by hurricane Rita a few days later), resulted in the largest natural disaster in US history and devastated human and economic landscape along the U.S. Gulf Coast. This disaster brought to the forefront a problem, recognized for decades, of adaptation to the Mississippi Delta sinking, which results in extensive wetland loss and increases the exposure of population, economic activities and infrastructure to hurricane-induced storm surges [Syvitski et al. 2009]. Dai et al. [2009] have shown that during the twentieth century approximately $25 \%$ of the Mississippi wetlands were lost to the ocean. The largest factor contributing to the wetlands loss is the construction of artificial levees, reducing the number of sediment pathways into adjacent flood plain basins [Kesel 2003]. This land-loss problem is exacerbated by trapping of 50\% of the total sediment load by upstream dams, and there is not enough supply to keep pace with subsidence and accelerated sea-level rise [Blum and Roberts 2012]. Assuming an acceleration of sea level rise from 3 to $4 \mathrm{~mm} / \mathrm{yr}$ and a subsidence rate from 1 to $1.7 \mathrm{~mm} / \mathrm{yr}$, coupled with the absence of sediment input, Blum and Roberts [2009] projected a potential submergence of $25 \%-30 \%$ of the delta $(\sim 10,000-13,500 \mathrm{~km} 2)$ by the year 2100. Blum and Roberts [2012], concluded that significant drowning is inevitable, even if sediment loads are restored, because the sea level is now rising at least three times faster than during the period of the delta-plain formation. 
Moreover, anthropogenic effects including locally accelerated subsidence can exacerbate this problem. Becker et al. [2014] estimated that $68 \%(\sim 4 \mathrm{~mm} / \mathrm{yr})$ of the sea level rise recorded at Galveston over the last century is too large to be due to natural sea level variability and, by consequence, should be dominated by land subsidence probably induced by extraction of subsurface fluids, hydrocarbons, and groundwater withdrawal [Morton et al. 2006; Kolker et al. 2011].

361 Kolker et al. [2011] used the Grand Isle, Galveston and Pensacola TG records from the RLR PSMSL dataset to investigate the subsidence rate in the northern part of U.S. Gulf over 19472006. They assumed that the Pensacola record, located on a stable carbonate platform, experiences a linear land movement and therefore subtracted the Pensacola from the others records to remove interannual variability. In doing so, they underlined three distinct significant subsidence phases i) 1947-1958: $3.1 \mathrm{~mm} / \mathrm{yr}$ and $2.6 \mathrm{~mm} / \mathrm{yr}$; ii) $1959-1991: 9.8 \mathrm{~mm} / \mathrm{yr}$ and 6.2 $\mathrm{mm} / \mathrm{yr}$; and iii) 1992-1996: $1 \mathrm{~mm} / \mathrm{yr}$ and $-2 \mathrm{~mm} / \mathrm{yr}$ at Grand Isle and Galveston respectively. They argued that the recent subsidence rates are lower than predictions of the subsidence scenario suggested by Blum and Roberts [2009] and, perhaps, future land losses linked to the subsidence will be limited. However, in updating Kolker et al. [2011] work we obtained a subsidence rate of $\sim 3 \mathrm{~mm} / \mathrm{yr}$ at Grand Isle over 1992-2015 (and $\sim 0.8 \mathrm{~mm} / \mathrm{yr}$ at Galveston, Table 4.3). This result is closer to the estimation of Morton et al. [2006] who reported a subsidence rate of $\sim 4 \mathrm{~mm} / \mathrm{yr}$ over 1993-2006. Moreover, our estimates agree with recent work by Letetrel et al. [2015], who combined satellite altimetry data and the long-term Grand Isle TG record and estimated a subsidence rate of $\sim 5 \mathrm{~mm} / \mathrm{yr}$ over 1992-2008 and $\sim 7 \mathrm{~mm} / \mathrm{yr}$ over 1947-2011. These values are close to the GPS-derived vertical velocity of $\sim-6.5 \mathrm{~mm} / \mathrm{yr}$ over $2005-2016$, estimated from GRIS GPSstation, $100 \mathrm{~m}$ from the Grand Isle TG.

The observed subsidence results from a combination of different processes such as tectonics, sedimentation, glacial isotactic adjustment, and anthropogenic fluid withdrawal [Douglas, 2001]. Various studies estimated present-day subsidence rates in the range of $2-10 \mathrm{~mm} / \mathrm{yr}$, as a response to the delta sedimentary load [Jurkowski et al. 1984; Ivins et al. 2007; Syvitski 2008; Törnqvist et al. 2008]. However, Wolstencroft et al. [2014] argued that the viscoelastic deformation due to sediment loading alone is unlikely to exceed $\sim 0.5 \mathrm{~mm} / \mathrm{yr}$. Thus, the current high rates of observed subsidence are likely to be linked to sediment compaction and fluid extraction. 
In the RLR PSMSL dataset, we found 20 TG stations, with time spans of more than 30 years, distributed along the coast of the Gulf of Mexico. 17 stations are located in the United States, two in Mexico and one in Cuba. The long-term RSL trends are gathered in three clusters. The first one represents the western coast from Progresso to Rockport (4 TGs) where the sea level rises at 3-5 mm/yr. The fastest RSL rise is observed at 6 TG situated along the northern coast from Freeport to Grand Isle in the Mississippi delta. Conjugation of land subsidence with rising ASL results in an RSL of 6-10 mm/year. The third cluster contains moderate RSL trends of 2$4 \mathrm{~mm} / \mathrm{yr}$ observed at 10 TGs in the eastern Gulf, from Dauphin Island to Key West. As in other regions, the main driver of the enhanced sea level rise in the Gulf of Mexico is in the deltaic region, and is due to land subsidence.

\subsubsection{Atlantic Eastern border: Gulf of Guinea}

397 The Gulf of Guinea, located in the eastern Equatorial Atlantic, is constituted of eighteen coastal States from Senegal to Angola. Its $12000 \mathrm{~km}$-long coastline is characterized by typical lowlying topography, coastal lagoons and by two large deltas: The Niger Delta and the Volta River Delta (Figure 4.1).

This coastline hosts 12 townships, each with a population of over 1 million, which is highly vulnerable to the impacts of climate change [UN-HABITAT 2014]. Moriconi-Ebrard et al. [2016] highlight the formation of an urban band of high population density by 2020, in the coastal area of the Gulf of Guinea. Yet, this region is already extremely vulnerable to projected sea level rise impacts (erosion, submersion, saline intrusion into coastal aquifers and agricultural areas, fisheries, mangrove degradation) [Nicholls and Mimura 1998].

Jallow et al. [1999] estimated, by modeling the effects of coastal erosion and a rise in sea level, that Banjul, the capital of the Gambia, can disappear by 2050. Dasgupta et al. [2009] ranked Benin in the top ten, of 84 developing coastal countries worldwide, which would be most impacted by a 1-m sea-level rise in terms of population to be displaced (4\%) and wetland area

411 loss (14\%) and Gambia in terms of land area loss (1\%). According to Brown et al. [2011], 412 Cameroon ranks in the top ten African countries likely to be impacted by flooding and forced 413 migration by 2100. Hinkel et al. [2012] concluded that Nigeria is one of the most vulnerable 414 African countries both in terms of the people-based sea level impacts as well as in terms of 415 economic costs. Some 25 million people are estimated to live currently within its coastal zones, 416 with about 8.5 million beneath the two-meter inundation contour [French et al. 1995]. The 
417 largest city, Lagos, is expanding rapidly across the land standing below a meter above sea level.

418 As much as $70 \%$ of the city's population live in slums characterized by extremely poor 419 environmental conditions, including regular flooding of homes that lasts several hours and that 420 sweeps raw sewage [Adelekan 2009]. In the Niger delta region, even in absence of acceleration 421 in absolute sea-level rise, the land loss through edge erosion alone can cause shoreline recession 422 of $3 \mathrm{~km}$ by the year 2100 [French et al. 1995]. Moreover, the Niger Delta is sinking much faster 423 than global sea level is rising [Syvistki et al. 2009]. The high subsidence rate (25-125 mm/year, 424 [Abam, 2001]), due to oil and gas extraction, combined with a reduction in sediment deposition 425 plus accelerated compaction of sediment, makes this delta along with the Nile River Delta the 426 most threatened of the African deltas [Syvistki et al. 2009].

427 Relatively little research on long term sea level change has been undertaken previously over 428 the African continent, because the existing African dataset is shorter than that in other parts of the world [Emery and Aubrey 1991; Woodworth et al. 2007]. The lack of historical data on sealevel rise in Africa makes it difficult to assess coastal impacts and vulnerability with accuracy.

431 Woodworth et al. [2007] reviewed the African sea level changes by using the PSMSL data set. 432 In the Gulf of Guinea, some records exist but with less than 20 years of data available and no 433 recent data. In the RLR PSMSL data bank, only two TG records from this region have relatively 434 recent data but with substantial missing or inconsistent data: Dakar 2 (1992-2014, 73\% of 435 completeness, Senegal) and Takoradi (1929-2012, 79\% of completeness, Ghana). In conclusion, along of the Gulf of Guinea coastline, only the Takoradi TG record, with reliable datum continuity, can be used to estimate a long-term RSL trend over 36 years (1930-1965), which is $\sim 3 \mathrm{~mm} / \mathrm{yr}$ [Woodworth et al. 2007].

439 In this context of lack of data, Wöppelmann et al. [2008] have initiated investigations at Dakar 440 (Senegal) to find and rescue past sea-level records. Several decades of sea level observations at 441 Dakar have been found, the earliest dating back to 1889. The secular RSL trend estimated from 442 this long reconstructed TG is $1.6 \pm 0.2 \mathrm{~mm} / \mathrm{yr}$ from 1900 to 2011 . Using satellite synthetic 443 aperture radar interferometry (SAR), Le Cozannet et al. [2015] showed that despite a complex 444 geology, a rapid population growth and development in Dakar, the historical TG does not seem 445 to be affected by local vertical coastal land motion, and therefore can be a good candidate for 446 sea level studies in the Gulf of Guinea as well as for past sea level reconstruction. The rate of 
ASL rise along the coast of the Gulf of Guinea is in the range 1.8-3 mm/yr (Figures 4.3 and

449 Due to the lack of TGs, it is difficult to assess all the causes of sea level variations along the

450 West African coast. Melet et al. [2016] determined the processes responsible for coastal sea

451 level variability in the Gulf of Guinea over the 1993-2012 period. They showed that in Cotonou

452 (Benin), the sea level trend is largely dominated by the same ocean signal as observed in the 453 altimetric data and, to a lesser extent, by interannual variability of the wave run-up height.

454 In the late 1990s, the Ocean Data and Information Network for Africa (ODINAFRICA, 455 www.odinafrica.org) project was initiated in order to develop an African sea level observing 456 network as part of the GLOSS Core Network, and rescue historical sea level data. Today, this 457 project brings together more than 40 marine-related institutions from 25 African countries to 458 address the challenges of accessing data and information for coastal management.

\subsubsection{Tropical Atlantic RSL hotspots: Summary}

- Guyana, Suriname and French Guiana are in the world top 10 countries mostly impacted by a $1-\mathrm{m}$ sea-level rise [Dasgupta et al. 2009]. About $6 \%$ of people in these regions would be displaced, leading to high probability of climate-induced massive population displacements.

- Brazilian coast: The enhanced sea level rise at Cananeia makes it a sea level hotspot. Is the RSL trend at Cananeia a local anomaly or should it be seen as a typical value along the

- Cartagena in Colombia: With a RSL trend faster than $5 \mathrm{~mm} / \mathrm{yr}$ and 1 million inhabitants, Brazilian coast? It is difficult to answer this question now, as the number of long-term TGs this is a site of great concern. The problem is complicated by the fact that contribution of land movement to the observed RSL is not yet reliably established. Consequently, any projections of future RSL changes should be assessed with due care.

- Northeastern coast of the Gulf of Mexico: The region within and around Mississippi delta is experiencing the fastest RSL rise measured by TGs in the tropical Atlantic. Land movement, due to sedimentation processes and water/oil/gas withdrawals, drives the longterm RSL changes in this region. 
Preprint of: Becker, M., Karpytchev, M., \& Papa, F. (2018). Hotspots of relative sea level rise in the Tropics. In Tropical Extremes Natural Variability and Trends (pp. 203-251). Elsevier. Retrieved from www.elsevier.com/books/tropical-extremes-natural-

variability-and-trends/vuruputur/978-0-12-809248-4

- Niger Delta is sinking much faster than GMSL is rising [Syvistki et al. 2009]. The high subsidence rate (25-125 mm/year), due to oil and gas extraction, combined with reduction in aggradation plus accelerated compaction of sediment, makes this delta, along with the Nile River Delta, the most threatened among the African deltas [Syvistki et al. 2009].

\subsection{Pacific Ocean}

\subsubsection{Central America and South America}

The Pacific coast of South America is a tectonically active zone driven by subduction of the Pacific plate. Little information about the long-term RSL trends along this coast is available, except from the earlier analysis by Aubrey et al. [1988] and Emery and Aubrey [1991] who have reported highly variable sea level trends with changing signs all along the coast of Chile and Peru. These trend variations were attributed to non-uniform tectonism, faulting and segmentation of subducting lithosphere. Inspecting the updated PSMSL RLR data set, we found 9 TG records spanning more 30 years from Mexico to Chile. An interesting result is that, along the west coast of South America, 5 of 6 long-term stations (Figure 4.2 and Table 4.4) reveal a decreasing RSL with a trend of about $-1 \mathrm{~mm} / \mathrm{yr}$. This value indicates a coastal uplift at a rate of $\sim 2 \mathrm{~mm} / \mathrm{yr}$ provided that we take $\sim 1 \mathrm{~mm} / \mathrm{yr}$ as a trend of ASL rise along the coast of ChilePeru from altimetry (Figure 4.3). Obviously, this evaluation should be taken with care because trend uncertainties are quite large (Table 4.4 and Figure 4.3). Notice, nevertheless, that a 2 $\mathrm{mm} / \mathrm{yr}$ land emergence was detected by GPS at Callao, although this value was estimated from 5-year long measurements (Table 4.4). As to the southern most tropical Chilean TG Caldera, it manifests a positive RSL trend of about $2.8 \mathrm{~mm} / \mathrm{yr}$, which is larger than $1.7 \mathrm{~mm} / \mathrm{yr}$ estimated by Emery and Aubrey [1991] from a shorter period. The noticeable difference between our estimates and those of Emery and Aubrey [1991] might result from significantly longer time series used in our analysis. The long-term series are necessary to separate the trend from interannual and, especially, decadal sea level fluctuations that are particularly strong in this region. These low-frequency sea level variations are driven by El Niño and have been extensively investigated since 1960s [Roden 1963; Wyrtki 1973, 1975; Mitchum and Wyrtki 1988; Enfield 1989; Clarke 2014]. Recently, Losada et al. [2013] estimated that ENSO explains more than $65 \%$ of the mean sea level variance along the Peruvian coast. According to Reguero et al. [2015], the number of inhabitants affected by El Niño events, in addition to future sea level rise, will be substantial not only in Peru and Ecuador but in Panama, El Salvador, Costa Rica and Guatemala impacting more than $30 \%$ of population in these countries. Hallegatte et 
al. [2011], in a global study of losses due to future floods in coastal cities, identified Guayaquil, the largest and the most populated city in Ecuador, to be at particularly high risk.

510 Farther northward, in Central America, the century-scale Balboa record, the longest on the

511 American tropical coast, shows a RSL trend of about $1.5 \mathrm{~mm} / \mathrm{yr}$ that is comparable to the ASL

512 trend measured by altimetry (Figure 4.3). The two available 30-year long Mexican TGs have

513 large, statistically significant, RSL trends. Acapulco, with more than 700000 inhabitants, faces 514 sea level rising at a rate of $8.4 \mathrm{~mm} / \mathrm{yr}$ that places this city as a RSL hotspot: the RSL is rising 515 here at the rate among the fastest measured worldwide. A smaller $(4.4 \mathrm{~mm} / \mathrm{yr})$ but yet 516 appreciable RSL trend was estimated at Guaymas, a low-lying city in northwestern Mexico. 517 Along the Mexican South Pacific coast, the altimetry dataset has non-significant ASL trend 518 over the last 22 years. Buenfil-López et al. [2012] showed that the RSL in this region is affected 519 by seismic activity that can generate instantaneous fall in sea level. The GPS stations in Mexico have not yet provided reliable long-term estimates and we cannot reliably evaluate the land movement contribution to the observed RSL rise at Acapulco and Guaymas.

\subsubsection{Southeast Asia}

523 Approximately 20\% ( 134 million) of the world's population living in a contiguous area along 524 the coast, within less than 10 meters above sea level, can be found in seven Southeast Asian countries: Vietnam, Cambodia, Thailand, Indonesia, Philippines, Malaysia, and Singapore (LECZ database, Figure 4.1). The first four are among the top 10 countries in the world with the highest number of people living within less than $10 \mathrm{~m}$ above sea level [McGranahan et al. 2007]. Most of the megacities in this region are located either in coastal areas or within a large delta, with rich alluvial soils used for agriculture and aquaculture. A series of rapidly

530 developing megacities is located in large deltas, such as Bangkok ( $\sim 6$ million inhabitants), the

531 capital of Thailand in the Chao Phraya River delta (Figure 4.1) and Ho-Chi-Minh city 532 (Vietnam), of $\sim 8$ million inhabitants situated in the Mekong River Delta (Figure 4.1). The natural resources in this region will also be profoundly impacted by RSL. Thus, concerning the mangrove forest persistence in Indo-Pacific region, Lovelock et al. [2015] projected that some sites subject to sea level rise, with low tidal range and low sediment supply, could be submerged

536 by 2070s. This is the case in Chao Phraya and Mekong deltas, where vulnerability to sea level 537 rise is exacerbated by anthropogenic activities, as groundwater extraction and dam construction 538 [Lovelock et al. 2015]. In southern China, the Pearl River Delta, one of the most populated areas 
in the Chinese mainland [Wolanski 2006], is home to several megacities ( $\sim 8$ million inhabitants each) as Shenzhen, Guangzhou, and Hong Kong. Hanson et al. [2011] evaluated the exposure of the population of the world's large cities to coastal flooding hazard by 2070 s, and concluded that only twelve countries contain $90 \%$ of the total of 148 million people exposed. (China $(21 \%)$, Vietnam (9\%), Thailand (3\%), and Indonesia (2\%) are among the top 10 countries.) They also pointed that the exposure in 2070s varies disproportionately in deltas among the top 10 cities: Guangzhou ( $\sim 10$ million people exposed), Ho Chi Minh City ( $\sim 9$ million), Bangkok ( $\sim 5$ million) and Hai Phòng ( $\sim 5$ million, Vietnam).

We updated analyses of TG records from eastern Asia previously performed by Emery and Aubrey [1986, 1991] and Yanagi and Akaki [1994]. The sea level records selected from the PSMSL database are the RLR series spanning at least 30 years, except for two stations Kota Kinabalu and Tawau (28 years) which are the only available data from Borneo Island (Table 4.5). We investigated for significant RSL trends in this region, from Vietnam to South China. In Vietnam, we found 3 significant RSL trends: in the North at Hondau, $2 \mathrm{~mm} / \mathrm{yr}$, and in the South at Danang and Vungtau, on an average, $3.4 \mathrm{~mm} / \mathrm{yr}$. There are no TGs from Cambodia available at PSMSL; the same is the case with the Mekong delta, though more than $20 \%$ of the national population lives in this area, which is also a vital agricultural zone. Fujihara et al. [2015] analyzed water level trends from 24 river gauge stations (over 1987-2006) managed by the Mekong River Commission. These stations located in the delta, and influenced by both inflow from upstream and tidal action from the South China Sea and the Gulf of Thailand, can also deliver relevant information about the RSL. Fujihara et al. [2015] estimated a RSL trend of $7.4 \mathrm{~mm} / \mathrm{yr}$ over 1987-2006 in the Mekong Delta, attributing 20\% of this trend to ASL rise and $80 \%$ to land subsidence. Erban et al. [2014], using interferometric synthetic aperture radar (InSAR), estimated a rate of land subsidence, mainly due to groundwater pumping, throughout the Mekong Delta in the range 10-40 mm/yr during 2006-2010. Their projection is that, if pumping continues at this rate, a land subsidence of $\sim 0.9 \mathrm{~m}(0.35-1.4 \mathrm{~m})$ is to be expected by 2050.

There are 3 long-term TG records available from Thailand. In the cities of Ko Sichang and Ko Lak, we estimated an RSL rate of $0.8+/-0.5 \mathrm{~mm} / \mathrm{yr}$. The Fort Phrachula TG is located at the coast of the Chao Phraya delta, just south of Bangkok, and it has an RSL trend of $\sim 15 \mathrm{~mm} / \mathrm{yr}$. This very fast RSL rise, is due to land subsidence induced partly by natural compaction of deltaic sediments and amplified by overpumping of groundwater, changing non-linearly with 
time since 1955 [Emery and Aubrey, 1991; Phien-wej et al. 2006]. Over the past 35 years, the land subsidence rate reached $120 \mathrm{~mm} /$ year and nowadays ranges from 20 to $30 \mathrm{~mm} / \mathrm{yr}$ [Phienwej et al. 2006]. The work of Phien-wej et al. [2006] suggests that for each $1 \mathrm{~m}^{3}$ of groundwater pumped out in the Bangkok Plain, it is approximately $0.10 \mathrm{~m}^{3}$ of ground that is lost at surface.

In Peninsular Malaysia, the average RSL trend, estimated from 4 TGs, in operation since 1980s to 2015 , is about $\sim 3 \mathrm{~mm} / \mathrm{yr}$. At the southern tip of the Malaysian Peninsula, in Singapore, the RSL trend is about 2-3 mm/yr since 1970s. These estimates are consistent with the results of Tkalich et al. [2013] who reported an RSL trend of $\sim 2.3 \mathrm{~mm} / \mathrm{yr}$. The Singapore mainland is subsiding at a rate of $1.5-7 \mathrm{~mm} / \mathrm{yr}$ [Catalao et al. 2013].

Along the Indonesian Pacific Coast, there are no RLR TGs available at PSMSL. However, Fenoglio-Marc et al. [2012] used two TGs located on the Pacific coast of Java province from the Metric PSMSL database: Jakarta (1993-2011) and Surabaya (1993-2009). In Surabaya, they estimated an RSL trend of $8.8 \mathrm{~mm} / \mathrm{yr}$ and $-21.3 \mathrm{~mm} / \mathrm{yr}$ at Jakarta, compared to an ASL trend of $3.8 \mathrm{~mm} / \mathrm{yr}$ from altimetry at both locations. Combining these two techniques, they detected a high land subsidence rate at Jakarta of $-19.7 \mathrm{~mm} / \mathrm{yr}$ and of $-5.3 \mathrm{~mm} / \mathrm{yr}$ at Surabaya. The megacity of Jakarta ( $\sim 10$ million inhabitants) is located in a lowland area in the northern coast of West Java and is subject to land subsidence mainly induced by excessive groundwater extraction [Abidin et al. 2010]. From levelling surveys, GPS observations and InSAR analysis, Abidin et al. [2015] estimated the rate of land subsidence in Jakarta in the range $30-100 \mathrm{~mm} / \mathrm{yr}$ during 1974-2010. Chaussard et al. [2013] performed a global survey of Sumatra and Java, using a method of differential SAR interferometry (D-InSAR), and identified land subsidence in 5 major coastal cities, mainly due to groundwater extraction, in the range $20-240 \mathrm{~mm} / \mathrm{yr}$ during 2006-2009. Moreover, at Jakarta, Hanson et al. [2011] estimated that more than 2 million people will be exposed to coastal flooding by 2070s. Considering the Coral Triangle countries, including Indonesia, Malaysia, Philippines, East Timor, Papua New Guinea, and the Solomon Islands, Mcleod et al. [2010] demonstrated that the sea level rise (scenario: sea level rises up to $0.4 \mathrm{~m}$ by 2100 and without adaptation) will significantly affect coastal population and habitats, and Indonesia will be a country which is likely to be most affected by coastal flooding, with $\sim 6$ million people impacted annually by 2100 . 
In East Malaysia, located on the island of Borneo, only two long TGs are available and both they manifest a strong RSL trend of $\sim 4 \mathrm{~mm} / \mathrm{yr}$ since 1990s, consistent with the ASL trend from altimetry (Figure 4.3 ) over the same period.

603 In Philippines, 5 acceptable TGs (Figure 4.2) are available, and they span 44 to 68 years. The

6043 TGs located on the eastern side of the archipelago have high RSL trends of: $\sim 5.5 \mathrm{~mm} / \mathrm{yr}$ at 605 Davao and Legaspi; and $\sim 14 \mathrm{~mm} / \mathrm{yr}$ in Manila. In the west, the Cebu TG has a RSL trend of $6060.9 \mathrm{~mm} / \mathrm{yr}$. These differences in trend can be explained by land subsidence, which is larger on the eastern side of the subduction zone, and there is a marginal land uplift on the opposite side [Emery and Aubrey 1991]. In Manila, Rodolfo and Siringan [2006] showed that a much higher rate of RSL is induced by land subsidence, linked with the increase in groundwater pumping and consistent with the population growth curve over the same period. The GPS station (PIMO $2.7 \mathrm{~mm} / \mathrm{yr}$, Table 4.5), located $13 \mathrm{~km}$ northeast from the TG, and the DORIS station (3.2 $\mathrm{mm} / \mathrm{yr}$ ), located $10 \mathrm{~km}$ southeast from the TG, show, in agreement, an uplift rather than subsidence [Santamaría-Gómez et al. 2017]. This indicates a significant spatial variation in vertical displacements around the TG. Raucoules et al. [2013] demonstrated, from D-InSAR, that Manila was locally affected by vertical ground motions of about $15 \mathrm{~cm} / \mathrm{yr}$ from 1993 to 2010. Therefore, the impact related to human-induced subsidence is already evident in Manila city. In this context, the results of Perez's et al. [1999] on vulnerability analysis suggest that most areas along the coast of Manila Bay (including Manila city) could succumb, from both physical and socio-economic standpoints, to a $1 \mathrm{~m}$ sea level rise by 2100 .

620 In South China, we found 3 TGs with a time span of at least 50 years. We estimated RSL trends 621 of: $\sim 2 \mathrm{~mm} / \mathrm{yr}$ at Kanmen and Zhapo, and $\sim 1 \mathrm{~mm} / \mathrm{yr}$ at Xiamen. Tseng et al. [2010] estimated 622 from TGs, around Taiwan, an RSL trend of $2.4 \mathrm{~mm} / \mathrm{yr}$ from 1961 to 2003 and $5.7 \mathrm{~mm} / \mathrm{yr}$ during the period 1993-2003. Ding et al. [2001] estimated an RSL trend at Hong Kong around 2 $\mathrm{mm} / \mathrm{yr}$ over 1954-1999. Two TG records in Hong Kong from the RLR PSMSL dataset have similar RSL trends of $\sim 3 \mathrm{~mm} / \mathrm{yr}$ (Table 4.5). Guo et al. [2015] estimated vertical land movement

626 along the South China coast from TGs and satellite altimetry, and found subsidence rates 627 varying from 6 to $17 \mathrm{~mm} / \mathrm{yr}$. At Shenzhen, land subsidence at a rate of $25 \mathrm{~mm} / \mathrm{year}$ was detected 628 over 2007-2010, by the method of Small Baseline Subset InSAR (SBAS-InSAR, Xu et al. 2016). In the Pearl River Delta, the RSL changes seem to be essentially controlled by vertical movements of active faults [Mei-e, 1993]. He et al. [2014] reconstructed the regional sea level, 
risen at a rate of $4 \mathrm{~mm} / \mathrm{yr}$ in the Pearl River Delta. They determined different spatial patterns of variability in the river mouth and along the coastline. In this region, there is no clear consensus on the causes of long-term RSL changes. Many more studies are urgently needed to understand the causes of observed RSL changes in order to mitigate potential disasters associated with future SL rise

In light of the results mentioned above, the major concern of this region is that the rates of RSL rise are one to two times higher (and much more at Bangkok and Manila) than the GMSL trend over the $20^{\text {th }}$ century. These results are confirmed by estimates from the sea level reconstruction (Figure 4.4) that vary around $\sim 3 \mathrm{~mm} / \mathrm{yr}$ since 1960 and 3-5 mm/yr since 1993 (Figure 4.3).

Recent analysis of the regional sea level variability in the Gulf of Thailand, including GPSderived rate of vertical land movements, provides a rate of ASL rise of about $5 \mathrm{~mm} / \mathrm{yr}$ since 1940s and 3-6 mm/yr over the altimetry era [Trisirisatayawong et al. 2011]. In this region, the impact of the post-seismic motion due to the 2004 Sumatra-Andaman earthquake on the RSL rate is of the order of $-10 \mathrm{~mm} / \mathrm{yr}$ [Trisirisatayawong et al. 2011]. Furthermore, there are indications that RSL rates increased significantly at all locations $(20-30 \mathrm{~mm} / \mathrm{y}$ almost everywhere [Saramul and Ezer 2014]) after this earthquake.

Many studies have shown that in South China Sea, the interannual sea level variations are linked to ENSO [Rong et al. 2007; Han and Huang 2009; Peng et al. 2013] and to the Pacific Decadal Oscillation (PDO, [Deng et al. 2013; Wu et al. 2014; Strassburg et al. 2015]). The Indian Ocean Dipole (IOD) influences interannual sea level variations in the southwestern (Malaysia Peninsula and Singapore Strait) and southeastern (Borneo Island) coastal regions [Soumya et al. 2015]. The sea level trends are greatly masked by a low-frequency variability associated with the PDO [Strassburg et al. 2015; Cheng et al. 2016]. Since 1990s, there has been a major phase shift of PDO; this phase shift is associated with an intensification of the trade winds at the equator, storing warm water and increasing sea level in the western tropical Pacific, and reducing it along the west coast of the Americas [Merrifield et al. 2012]. Hence, the accelerated sea level rise seems to be a part of global adjustment to this PDO phase shift [Cheng et al. 2016]. Thus, it is important to take into account this natural decadal variability in the future sea level trend estimates in the South China Sea, where sea level rise expected to be much more intense.

\subsubsection{Western Tropical Pacific (WTP) Islands}


663 Over the past several decades, there is a large scientific consensus on the threat hanging over small islands, and, particularly, on the western tropical Pacific (WTP) islands, due to rising sea levels associated with global warming [Nurse et al. 2014]. The future stability, and survival, of 666 the nations of these small islands is a major international concern. A large number of studies, using TG data, altimetry observations, past sea level reconstruction and global models, have revealed patterns of a recent enhanced sea level trend in the WTP (among others [Church et al. 2004; Merrifield 2011; Becker et al. 2012; Merrifield et al. 2012; Meyssignac et al. 2012b; Zhang and Church 2012]). Inspecting the updated PSMSL RLR data set, we found 22 TG records spanning more than 30 years in the WTP region. Interestingly, 12 out of 22 long-term stations (Table 4.6) reveal an increasing RSL, with a trend greater than the $20^{\text {th }}$ century GMSL.

Merrifield [2011] highlighted an abrupt sea level rise in WTP since the early 1990s, compared to the last 40 years. Becker et al. [2012] showed that the RSL rate at Funafuti Island (Tuvalu) is $\sim 5 \mathrm{~mm} / \mathrm{yr}$ over 1950-2009, which is about 3 times larger than the GMSL rise over the same period. These results are confirmed by our estimates from the sea level reconstruction that estimates the trends in the range 4-5 mm/yr since 1960 (Figure 4.4) and 5-11 mm/yr since 1993 (Figure 4.3). In the WTP region, superimposed on these trends are transient interannual and decadal sea level variations of the order of $\pm 20-30 \mathrm{~cm}$ [Becker et al. 2012]. This interannual and decadal sea level variability is attributed to low-frequency Pacific trade wind fluctuations, associated with low-frequency modulations of ENSO and PDO [Merrifield, 2011; Zhang and Church 2012; Moon et al. 2015; Palanisamy et al. 2015]. However, the processes operating over longer timescales, and especially the influence of the Indian Ocean, are still under debate [Han et al. 2014; Moon et al. 2015; Mochizuki et al. 2016]. Han et al. [2014] argued that the intensified decadal and multidecadal sea level variability results from a phase shift in sea surface temperature between the Indian Ocean and tropical Pacific. In addition, at many islands in this region, the RSL can be affected by crustal deformation due to volcanic and tectonic activities. For example, Ballu et al. [2011] reported large earthquake-related land subsidence at the Torres Islands (Vanuatu) between 1997 and 2009, which added to the absolute sea level, generating RSL rise of $\sim 20 \mathrm{~mm} / \mathrm{yr}$.

693 The increased island sensitivity to changes in human settlement patterns, and in socioeconomic and environmental conditions, makes it far more difficult to detect and attribute climate change effects. This also remains a source of debate in the scientific community [Nurse et al. 2014]. 
Preprint of: Becker, M., Karpytchev, M., \& Papa, F. (2018). Hotspots of relative sea level rise in the Tropics. In Tropical Extremes: Natural Variability and Trends (pp. 203-251). Elsevier. Retrieved from www.elsevier.com/books/tropical-extremes-natural-

variability-and-trends/vuruputur/978-0-12-809248-4

Over the past few decades, from a limited number of studies, no clear linkage between WTP island shoreline recession and recent sea level rise was found [Webb and Kench 2010; Le Cozannet et al. 2013; Kench et al. 2015; McLean and Kench 2015; Duvat and Pillet 2017] but net changes in shoreline position have been observed. However, Kench et al. [2015] question the islands' capacity to continue maintaining their current dynamic adjustment to higher rates of sea level change, as those expected by 2100. A recent study by Albert et al. [2016] highlights that the rates of some Salomon Islands shoreline recession are substantially higher in areas exposed to high wave energy, indicating a synergistic interaction between sea level rise and waves. Therefore, shoreline changes and floods seem to result from extreme events, and from maladaptive trajectories exacerbated by the sea level rise [Duvat et al. 2013].

\subsubsection{Tropical Pacific RSL hotspots: Summary}

- Acapulco (Mexican South Pacific coast) with more than 700000 inhabitants faces a sea level rise at a rate of $8 \mathrm{~mm} / \mathrm{yr}$, one of the fastest rates along the Pacific coast of America.

- Mekong Delta is a hotspot with an RSL rise of $7 \mathrm{~mm} / \mathrm{yr}$ over 1987-2006. Fujihara et al. [2015] estimated that $80 \%$ of this rate is due to land subsidence. The delta is likely to subside even faster, at a rate of 10-40 mm/yr, as revealed by InSAR analysis over 20002010

- Chao Phraya Delta (Bangkok) faces an RSL rise of $15 \mathrm{~mm} / \mathrm{yr}$, but the current subsidence is probably larger, being about 20 to $30 \mathrm{~mm} / \mathrm{yr}$ [Phien-wej et al. 2006] with a milder ASL trend of $3-5 \mathrm{~mm} / \mathrm{yr}$.

- Jakarta megacity (Indonesia) is one of the world's cities most threatened by rising RSL with a high population density, fast land subsidence of $20 \mathrm{~mm} / \mathrm{yr}$ or larger (InSAR 20-240 $\mathrm{mm} / \mathrm{yr}$ ), and an enhanced ASL rate of 5-7 mm/yr.

- Manila megacity (Philippines) is an indisputable RSL hotspot due to land movement induced by a variety of processes in this region. The contribution of ASL rise (5-7 mm/yr) and the interannual variations due to ENSO are not negligible either. 
- Almost all the Western Tropical Pacific Islands are subject to pronounced ASL rise. In

combination with land subsidence induced by tectonic faults and the Pacific subduction
zone (e.g. Vanuatu), some of the WTP islands can face rapid coastal submergence in the

combination with land subsidence induced by tectonic faults and the Pacific subduction
zone (e.g. Vanuatu), some of the WTP islands can face rapid coastal submergence in the future.

733

734

735

Preprint of: Becker, M., Karpytchev, M., \& Papa, F. (2018). Hotspots of relative sea level rise in the Tropics. In Tropical Extremes: Natural Variability and Trends (pp. 203-251). Elsevier. Retrieved from www.elsevier.com/books/tropical-extremes-naturalvariability-and-trends/vuruputur/978-0-12-809248-4

\subsection{Indian Ocean}

\subsubsection{Bay of Bengal}

The Bay of Bengal (BoB), located in the northern Indian Ocean is surrounded to the east by Bangladesh and Myanmar, and to the west by India. The BoB is the largest bay in the world, and is unique in many ways. Today, a quarter of the world's population lives in its vicinity ( $\sim 1.5$ billion people from World Development Indicators, Mundial 2014) and more than 170 million people live below 10 m of coastal elevation (from LECZ, India - 7\%, Bangladesh $40 \%$, Myanmar $-25 \%$ and Sri Lanka - $13 \%$ in percentage of the respective national population, Figure 4.1). The population is being concentrated in megacities such as Kolkata (India, $\sim 15$ million inhabitants), Chennai (India, $\sim 10$ millions), and Dhaka (Bangladesh, $\sim 18$ millions), and in large urban agglomerations ( $\sim .5$ millions) such as Chittagong in southeastern Bangladesh and Yangon in Myanmar (Figure 4.1). Additionally, Dhaka and Kolkata are megacities located in the low-lying Ganges-Brahmaputra-Meghna (GBM) Delta, and Yangon in the Irrawaddy River Delta. Other major deltas along the India's east coast are the Krishna, Godavari and Mahanadi. Syvitski et al. [2009] revealed that all these deltas are already threatened by rising RSL. They classified the deltas as subject to: (i) high risk for the Krishna delta, due to virtually no deposition of sediment and accelerating compaction, (ii) greater risk: GBM and Irrawaddy deltas due to compaction of the soil exacerbating the low rate of sediment deposition; and (iii) significant risk: the Mahanadi and Godavari deltas, due to lower sediment deposition rates than that of ASL rise. The geographic and socio-economic situation of the BoB coast places it among the most vulnerable to climate change, and to RSL rise not only in South East Asia, but also in the world. Rao et al. [2008] demonstrated that, over the four past decades, pronounced coastal erosion along the Krishna and Godavari deltas is apparently due to sediment retention at dams. This result was confirmed by Gupta et al. [2012], who showed that increasing number of mega dams and reservoirs between 1978 and 2003 on the Krishna River (9 mega-dams), Godavari (9 mega-dams) and Mahanadi (2 mega-dams) could be an obvious reason for the observed decrease $(>70 \%)$ in sediment supply. Concerning the GBM delta, Sarwar and Woodroffe [2013], using 20 years of Landsat satellite images, noticed that the entire delta coast changed 
little and erosion and accretion are relatively balanced. However, Wilson and Goodbred [2015]

highlighted three regions where sediment supply is insufficient to offset subsidence or erosion: in the northeast (Sylhet Basin), along the Indian tidal delta plain and the fluvio-tidal transition in the western and central parts of the delta. Shearman et al. [2013] documented, from 20 years of Landsat satellite images, a net contraction of delta mangrove area, including the Sundarbans region.

The RSL changes along the eastern coast of India, from West Bengal to Sri Lanka have been previously estimated from two long-term ( $>60$ years) TGs at Vishakhapatnam and Chennai (RLR PSMSL) analyzed by: Emery and Aubrey [1989]; Unnikrishnan and Shankar [2007]; and Palanisamy et al. [2014]. These studies found consistent RSL trends equal to 0.6 and $0.8 \mathrm{~mm} / \mathrm{yr}$ at Chennai and Vishakhapatnam (Table 4.7), respectively. Both values are significantly smaller than the 20th century GMSL trend (still valid if GIA correction of $\sim-0.4 \mathrm{~mm} / \mathrm{yr}$ is applied). Both stations are located at the border of the tectonically stable Precambrian shield and their lower RSL trends were interpreted by Emery and Aubrey [1991] as consequence of land submergence. However, the altimetry-derived and reconstructed ASL trends (Figure 4.3 and 4.4) near the eastern coast of India are about $1 \mathrm{~mm} / \mathrm{yr}$ or larger than the RSL trends at Chennai and Vishakhapatnam. Thus, the subsidence of the eastern coast of India does not seem to be supported by these long-term RSL measurements.

In the northwest BoB, along the Hooghly River in West Bengal, Emery and Aubrey [1989] found erratic RSL rates between -7 to $6 \mathrm{~mm} / \mathrm{yr}$ at Saugor (1937-1982, 45yr, $4 \mathrm{~mm} / \mathrm{yr}$ ), Diamond Harbour (1948-1982, 35yr, -7 mm/yr), Kidderpore (1881-1931, 24yr, 6 mm/yr) and Kolkata (1932-1982, 50yr, -7 mm/yr). They finally omitted all these records because of a great influence of cyclonic storm surges, floods, sediment compaction and datum shifts. Nandy and Bandopadhyay [2011] estimated RSL trends based on three TGs ( $>30 \mathrm{yr})$ from the RLR PSMSL dataset (Table 4.7): $1.2 \mathrm{~mm} / \mathrm{yr}$ at Gangra (31 km from the sea coast), $2.8 \mathrm{~mm} / \mathrm{yr}$ at Haldia (43 $\mathrm{km}$ from the sea) and $4 \mathrm{~mm} / \mathrm{yr}$ at Diamond Harbour ( $70 \mathrm{~km}$ from the sea). They argued that this trend variability appears to originate from the morphology of the landward-narrowing estuary, with some contribution from sediment compaction. Brammer, [2014] detected a shift in 1975 in the Diamond Harbour TG, coinciding with the construction of the Farakka barrage across the Ganges. This construction, and probably other upstream engineering works, may have 
discharge, extending toward the freshwater zone to the mouth of the estuary and impacting the tidal regime [Sinha et al. 1997].

Shared by India and Bangladesh, in the north of BoB, the Sundarbans region is the world's largest contiguous mangrove forest that covers approximately $\sim 10000 \mathrm{~km}^{2}$ of the GBM delta, with $60 \%$ in Bangladesh and $40 \%$ in India [Iftekhar and Saenger 2008]. This area, directly threatened by sea level rise and alteration of freshwater flux, is recognized as a global priority for biodiversity conservation, especially regarding the Royal Bengal Tiger [Loucks et al. 2010]. Brown and Nicholls, [2015] reviewed available data, literature and documentary sources and created a database of subsidence rates in the Bengal delta. They concluded an average subsidence rate of $2.8 \mathrm{~mm} / \mathrm{yr}$ in Sundarbans region, the lowest rate observed in GBM delta. Loucks et al. [2010], using high resolution elevation data and a scenario of sea level increasing (by $28 \mathrm{~cm}$ ), warned that in 50 years the Sundarbans tigers could join the Arctic's polar bears on the list of victims of climate change-induced habitat loss. Rahman et al. [2011], using Landsat images, showed that the Sundarbans coastline is currently in net erosion and was losing on-an-average about $5 \mathrm{~km}^{2} / \mathrm{yr}$ over 1973-2010 ( 170km², i.e $\left.\sim 2 \%\right)$. Payo Garcia et al. [2016], through a numerical model with different sea level rise scenarios (rise by $46 \mathrm{~cm}$ or $75 \mathrm{~cm}$ ) and taking a net subsidence of $\pm 2.5 \mathrm{~mm} / \mathrm{yr}$, estimated that between 1 to $6 \%$ of Bangladesh

812 Sundarbans area could be lost by 2100 . The results obtained in this framework suggest that 813 erosion, rather than inundation, may remain the dominant land loss driver by 2100. Pethick and Orford [2013] showed a rapid rise in RSL in the Sundarbans area. They used the only three available TGs, provided by Institute of Water Modelling of Bangladesh: Hiron Point (34yr), Mongla (20yr) and Khulna (72yr). In the RLR PSMSL dataset, we could find the Hiron Point and Khepupara TG records, but they turned out to be too short $(<24$ years) for long-term analysis. Pethick and Orford [2013] found strong RSL trends of: $\sim 8 \mathrm{~mm} / \mathrm{yr}$ at Hiron Point (at the mouth of Pussur Estuary), $\sim 6 \mathrm{~mm} / \mathrm{yr}$ at Mongla and $\sim 3 \mathrm{~mm} / \mathrm{yr}$ at Khulna (located $120 \mathrm{~km}$ inland). Moreover, they argued that the mean high water level was increasing at a much faster rate $(14-17 \mathrm{~mm} / \mathrm{yr})$ and a large part of the signal can be attributed to tide amplification, constricted by embankments.

824 Along other low-lying coastal regions of Bangladesh, high population density, inadequate 825 infrastructure and low adaptive capacity have made the urban residents highly vulnerable to climate change [Milliman et al. 1989; Choudhury et al. 1997; Warrick and Ahmad 2012]. Over 
$28 \%$ of the total population ( $\sim 88$ million) live in urban agglomerations (World Bank indicators [Mundial 2014]). This percentage, which was below 5\% in 1974, is expected to reach to $45 \%$ in 2030. At least $50 \%$ of the urban population ( 23 million) live in three major cities: Dhaka, Khulna, and Chittagong, where the land elevation, in whole or in part, is less than 10 meters above sea level. Hanson et al. [2011] estimated that more than 11 million people will be exposed to coastal flooding in 2070s at Dhaka, $\sim 4$ million at Khulna and $\sim 3$ million at Chittagong.

Higgins et al. [2014], using InSAR satellite-based technique and GPS over 2007-2011, mapped the subsidence within GBM delta in a region covering $\sim 10000 \mathrm{~km}^{2}$ of irrigated cropland surrounding Dhaka city. The subsidence rate is about $10 \mathrm{~mm} / \mathrm{yr}$ around Dhaka and may reach $18 \mathrm{~mm} / \mathrm{yr}$ elsewhere in the area. Brown and Nicholls [2015] reported subsidence rates in the range -1 to $44 \mathrm{~mm} / \mathrm{yr}$, with a mean of $\sim 3 \mathrm{~mm} / \mathrm{yr}$. These rates are associated with four principal processes: i) tectonics, ii) sediment compaction, iii) sedimentation, and iv) human activities such as groundwater extraction, drainage and embankment building.

Some studies tried to estimate the effect of future RSL rise on Bangladesh coast. Huq et al. [1995], among others, estimated that a 1-meter rise can flood $\sim 17 \%$ of land area and lead to displacement of more than 13 million people. Arfanuzzaman et al. [2016] estimated that with a $71 \mathrm{~cm}$ rise (with respect to 1980-1999 levels), up to 25\% of Bangladesh wetlands could be lost by 2100. Ruane et al. [2013] studied the impact of climate changes through different parameters on agricultural production in Bangladesh. They show that the agriculture production in southern Bangladesh is severely affected by sea level rise. The projections of production lost due to coastal inundation, associated with $27 \mathrm{~cm}$ of sea level rise, could reach $20 \%$ in southern Bangladesh (and 40\% with $62 \mathrm{~cm}$ sea level rise).

Finally, there is no clear consensus about the response of the GBM delta to natural and human forcings over decadal to century timescales. Moreover, all the studies on climate change impacts focused on coastal flooding by applying a simplified sea level rise scenario, yet an uncertainty of 10 centimeters of RSL rise may result in major consequences for local people [Lee 2013]. Despite the crucial importance of this problem, very few studies have focused on assessing the actual RSL rates along the Bangladesh coast. 
Singh [2002] estimated RSL trends from three TG records (22-year, 1977-1998) provided by the Bangladesh Inland Water Transport (BIWTA): in the west, at Hiron Point $\sim 4 \mathrm{~mm} / \mathrm{yr}$, in the center, at Char Changa $\sim 6 \mathrm{~mm} / \mathrm{yr}$ and, in the east, at Cox's Bazar $\sim 8 \mathrm{~mm} / \mathrm{yr}$. They argued that difference between these three RSL trends is probably due to local land subsidence in the eastern Bangladesh region (around Cox's Bazar). Lee [2013] used the Hiron Point TG record over 1990-2009 to reconstruct, by using ensemble empirical mode decomposition technique, the past RSL over 1950-2009 and found an RSL trend of $\sim 8 \mathrm{~mm} / \mathrm{yr}$. Sarwar [2013] used TG records, collected from the Bangladesh Water Development Board (BWDB), BIWTA and the Metric PSMSL dataset, and provided a comprehensive analysis of sea level changes in the region. They considered 13 TG records having at least 14 years of data, but a lot of discrepancies appeared in the trend analysis.

Along the Myanmar coast and within the Irrawady Delta, where $\sim 11$ million people live, only one long-term RLR TG record is available at PSMSL: the Yangon TG, operated during 19161962. Unfortunately, about $47 \%$ observations are missing in this record. There are also 3 old stations but with the record length under 10 years (Akyab, Moulmein and Amherst). It is an encouraging fact that since 2006 these locations have been re-instrumented and current data are now available from the Metric PSMSL dataset. The delta coast seems to be, more or less in equilibrium, and sediment deposition currently balances subsidence and sea level rise [Hedley et al. 2010]. This can be explained by fewer numbers of large dams relative to its Asian neighbors. However, this situation is now rapidly changing with extensive damming projects in the basin. At Yangon, Hanson et al. [2011] project that, by 2070s, more than 5 million people could be exposed to coastal flooding.

A large part of the recent RSL trends estimated in the eastern BoB can be attributed to the ASL rise. Over 1993-2014, the rate of ASL trend is in the range 3-5 mm/yr along the GBM coast and in the eastern part of the $\mathrm{BoB}$, and $1.8-5 \mathrm{~mm} / \mathrm{yr}$ along the eastern coast of India (Figure 4.3). Over 1960-2014, the sea level reconstruction gives an ASL trend of 2.5-3 mm/yr along the GBM coast and the eastern part of the $\mathrm{BoB}$, and in $1.8-2.5 \mathrm{~mm} / \mathrm{yr}$ along the east coast of India (Figure 4.4), which is greater than the $20^{\text {th }}$ century GMSL.

This finding was previously reported by Church et al. [2004], who found the fastest rate of ASL rise $(4-5 \mathrm{~mm} / \mathrm{yr})$ in the north-eastern Indian Ocean over the period 1955-2003. Han et al. 
893

894

895

[2010], combining in situ and satellite observations with climate model simulations, identified a significant sea-level rise since 1960s in Indian Ocean (except in its southern tropical region). They demonstrated that changing surface winds, linked to the strengthening of the Indian Ocean Walker and Hadley circulations, drive this pattern. However, a recent decadal reversal in the upper-ocean-temperature trends is observed in the North Indian Ocean (north of $5^{\circ} \mathrm{S}$, [Nieves et al. 2015]). An increase in the sea surface height decadal rate of $\sim 6 \mathrm{~mm} / \mathrm{yr}$ was estimated between the period of 1993-2003 and that of 2004-2013 from analysis of satellite altimetry data [Thompson et al. 2016]. Thompson et al. [2016] showed, through numerical model simulations, that this reversal has resulted from the combined effects of changing upper-ocean heat redistribution and the cross-equatorial heat transport, both being associated with decadal changes of surface winds.

\subsubsection{Arabian Sea, Persian Gulf and Maldives}

The Arabian Sea is a region, in the northwest part of Indian Ocean, at strikingly intense geopolitical and economic crossroads, notably via marine trade route for oil and gas resources export. We find the major harbors of Kochi and Mumbai on the southwest coast of India, and further in the northwest, the largest and most frequented ports serving the Arabian Sea, and, in the northeast, the major port of Karachi in Pakistan. Mumbai and Karachi are two large global megacities (with more than 10 million inhabitants, Figure 4.1). The city of Karachi had a high population growth rate of 5.3\% over 1960-2010 [Singh 2014]. On average, over the same period, Asian megacities faced an annual population growth rate of $3.7 \%$ against a rate of $2.6 \%$ in in the rest of the world [Singh 2014]. Mumbai, with a current population of about 20 million, expects to achieve a 35\%-growth rate by 2025, and in Karachi, the current population of 14 million is expected to see an increase of $45 \%$ by 2025 [Kourtit and Nijkamp 2013]. These cities already face major challenges of flooding and aquifer salinization, amplified by regional sea level rise. The situation is being further aggravated in the Indus Delta along Pakistan's coast, in Sindh province. This river system, among the largest deltas on Earth, is dominated by human activity since $19^{\text {th }}$ century and is presently affected by (1) artificial flood levees, (2) barrages and their irrigation canals, (3) sediment impoundment behind upstream reservoirs, and (4) interbasin diversion [Syvitski et al. 2013]. Consequently, there is a drastic reduction of sediment flux by more than 90\% [Giosan et al. 2006; Syvitski and Kettner 2011], which increases coastal retreat, seawater intrusion and flooding. Moreover, Ferrier et al. [2015] showed that, in the 
Indus delta over the past 100 years, as much as $\sim 0.5 \mathrm{~mm} / \mathrm{yr}$ of the sea level trend can be linked

to erosion and deposition of sediment since the last glacial-interglacial cycles. Another important process occurs in this specific region: the influence of the groundwater depletion, deforming the Earth's solid surface and depressing the geoid and slowing sea level rise near areas of significant groundwater loss [Veit and Conrad 2016]. Veit and Conrad [2016] define important groundwater depletion regions in Northwest India, Northeast Pakistan and in the Arabian Peninsula, with a consequential slowdown in sea level rise by $\sim 0.5 \pm 0.1 \mathrm{~mm} / \mathrm{yr}$ since 1930. Their work suggests that RSL in this region is currently as much as $\sim 50 \mathrm{~mm}$ lower than it would be in the absence of global groundwater depletion.

Emery and Aubrey [1989] investigated the relative long-term sea level from the Indian TGs during 1878-1982. On the west coast of India, they selected 3 TGs from the PSMSL dataset at Mumbai (also known as Bombay), Mangalore and Kochi (or Cochin) with a time length sufficient to detect significant changes. The longest and most coherent is the record of Mumbai (105 years, 1878-1982) presenting a significant linear sea level trend of $-0.9 \mathrm{~mm} / \mathrm{yr}$, followed by the Kochi record (43 years, 1878-1982) with a trend of $1.3 \mathrm{~mm} / \mathrm{yr}$ and the Mangalore series (24 years, 1953-1976) that has a $-2.1 \mathrm{~mm} / \mathrm{yr}$ trend. These trends show a strong discrepancy, probably due to differences in the record lengths. Unnikrishnan and Shankar [2007] conducted complete reanalysis of these records. They estimated significant RSL trends from PSMSL TGs having at least 40 years length. In Arabian Sea, the TGs of Aden (58 years, 1880-1969), Karachi (44 years, 1916-1992), Mumbai (113 years, 1878-1993), and Cochin (54 years, 1939-2003) were selected. The RSL rise estimated from these stations is between $1.1-1.7 \mathrm{~mm} / \mathrm{yr}$. We updated the RSL trends at Cochin to be $0.7 \mathrm{~mm} / \mathrm{yr}$ and at Mumbai to be $1.5 \mathrm{~mm} / \mathrm{yr}$ (Table 4.8), and $\sim 1.8-2.5 \mathrm{~mm} /$ yar from the sea level reconstruction (Figure 4.4). Over 1993-2014, the rate of sea level rise over the Arabian Sea from satellite altimeter is $\sim 1.5-3.5 \mathrm{~mm} /$ year (Figure 4.2). Although slightly lower, these estimates are consistent with GMSL rates.

Alothman et al. [2014] focused on the long-term sea level rise in the northwestern Persian Gulf. The average of 15 TGs records, obtained from PSMSL, produces a RSL rate of $2.4 \mathrm{~mm} / \mathrm{yr}$ for the period 1979-2007. Using 6 GPS stations, they estimated a subsidence rate of $-0.7 \mathrm{~mm} / \mathrm{yr}$ in this region, in part due to excessive pumping in agricultural areas and wetting of unstable soils [Amin and Bankher 1997]. 
The Maldives, located from $7^{\circ} \mathrm{N}$ to $0.5^{\circ} \mathrm{S}$ in the northeastern Arabian Sea, consists of 1190 small islands with $80 \%$ of the land area to be less than $1 \mathrm{~m}$ above sea level [Khan et al. 2002]. These atoll islands are morphologically sensitive to floods, tsunamis, and sea-level changes [Kench et al. 2006]. Several studies detected a recent trend of sea level rise at the Maldives [Khan et al. 2002; Woodworth 2005; Church et al. 2006; Palanisamy et al. 2014]. Palanisamy et al. [2014] compared two longest TGs: Malé and Gan ( 20 years of length, available from PSMSL dataset), with satellite altimetry and past sea level reconstruction. They inferred a significant rate of ASL rise at these two sites of $\sim 1.4 \pm 0.4 \mathrm{~mm} / \mathrm{yr}$ over 1950-2009. This rate is slightly lower than the GMSL rate over the same period. However, it only represents the climatic-component of sea level changes, and therefore does not take into account local subsidence that can amplify the RSL change, i.e., directly felt by the population. Now, it is crucial more than ever to estimate with accuracy the rate of vertical land motion at these sites, because the ongoing and future sea level rise subjects the population of the low-lying Maldives to enhanced vulnerability.

The nation of Mauritius, in the southwest, lives on a group of islands consisting of the main islands of Mauritius, Rodrigues and Agalega and the archipelago of Saint Brandon. Two TG records with 30-years length are available from the RLR PSMSL dataset in: the capital of 973 Mauritius Port Louis, where we found an RSL rate of $\sim 4 \mathrm{~mm} / \mathrm{yr}$, and the Rodrigues Island with an RSL trend of $\sim 6 \mathrm{~mm} / \mathrm{yr}$ (Table 4.8). These high rates are confirmed by the ASL trends from the sea level reconstruction (3-4 mm/yr,Figure 4.4) and from altimetry (5-7 mm/yr, Figure 4.3).

Globally, long-term, interannual and decadal changes in the sea level of the Arabian Sea have rarely been a subject of specific studies, probably due to the lack of historical quality data; the focus has primarily been on the regional physical oceanography of the northern Indian Ocean or that of the Bay of Bengal.

980 An important feature was highlighted by Clarke and Liu [1994] who pointed that the interannual sea level signal along the Indian west coast, from the equator to Mumbai, is generated by zonal interannual winds blowing along the equator. Shankar and Shetye [1999]

983 demonstrated that the interdecadal sea level variations recorded by the Mumbai TG closely 984 follow the monsoon rainfall over the Indian subcontinent. They explained this by the changes 985 in salinity in coastal waters, due to the seasonal fluctuations in river runoff, related to the 986 strength of the monsoon, and to the dynamics of ocean currents along the Indian coast. 
Preprint of: Becker, M., Karpytchev, M., \& Papa, F. (2018). Hotspots of relative sea level rise in the Tropics. In Tropical Extremes Natural Variability and Trends (pp. 203-251). Elsevier. Retrieved from www.elsevier.com/books/tropical-extremes-natural-

variability-and-trends/vuruputur/978-0-12-809248-4

Shankar et al. [2010] pointed to a much weaker interannual variability, in terms of low frequency, of the Indian west coast compared to the east coast. Aparna et al. [2012] demonstrated that the dominant climatic signals, IOD and ENSO, do not display any coherent response along the eastern Arabian Sea, in contrast to the Bay of Bengal. Suresh et al. [2013] showed that the Indian west coast intraseasonal sea level variations are mostly remotely forced by the winds from equatorial region and Suresh et al. [2016] demonstrated that winds near Sri Lanka drive $60 \%$ of Indian west coast and eastern Arabian Sea seasonal sea level. The Mumbai TG, the unique century-long TG record in the Indian Ocean, was used by Becker et al. [2014] to detect human influence on sea level rise. They provided statistical evidence, from the powerlaw statistics framework, that $64 \%$ (i.e, $\sim 0.7 \mathrm{~mm} / \mathrm{yr}$ ) of the observed sea level trend at Mumbai over the $20^{\text {th }}$ century could be induced by externally driven changes in the Indian Ocean currents.

\subsubsection{Indian Ocean RSL hotspots: Summary}

- Bangladesh coast is a sea level hotspot because of high density of coastal population that experiences devastating impact of cyclones on interannual time scale and RSL rise is enhanced by land subsidence on the decadal scale.

- Irrawaddy Delta is another sea level hotspot with 11 million people living in the region. A combination of 3-5 mm/yr in the ASL rise with land subsidence of $6 \mathrm{~mm} / \mathrm{yr}$ [Syvitski et al. 2009] leads to an RSL rise of more than $10 \mathrm{~mm} / \mathrm{yr}$.

- Mauritus Island: A site potentially threatened by an RSL rise of 4-6 mm/yr over the past 30 years, and an indication of the ASL rising 2 to 3 times faster than the $20^{\text {th }}$ century GMSL.

\subsection{Conclusion}

This chapter brings together sea level observations, and analyzes similarities and differences in past RSL changes along the tropical coasts. We first reviewed the concept of RSL and the drivers of its regional variations. We defined the RSL hotspots and described the different types of observations used to estimate it. Second, we have identified a number of RSL hotspots per oceanic basin. We highlighted the vulnerability of the tropical deltaic coasts, more specifically those of Asia, and a current knowledge gap for priority-populated areas such as Brazil, Indonesia, Philippines and Bangladesh. Obviously, this hotspot list is far from being exhaustive, 
Preprint of: Becker, M., Karpytchev, M., \& Papa, F. (2018). Hotspots of relative sea level rise in the Tropics. In Tropical Extremes: Natural Variability and Trends (pp. 203-251). Elsevier. Retrieved from www.elsevier.com/books/tropical-extremes-natural-

variability-and-trends/vuruputur/978-0-12-809248-4

1017

1018

1019

1020

1021

1022

1023

1024

1025

1026

1027

1028

1029

1030

1031

1032

1033

1034

1035

1036

1037

1038

1039

\section{Figures :}

because most of these regions are still not sufficiently well instrumented with quality TGs and collocated GPS stations. While waiting for obtaining in the future precise and accurate longterm sea level in situ measurements, new space missions are expected to provide unprecedentedly precise observations of sea level changes along the tropical coasts (e.g. the satellite missions Saral/Altika, Sentinel-3/6, Jason-CS, SWOT).

Understanding and forecasting of the RSL critical thresholds along low-lying heavily populated tropical coastlines are among the most vital societal issues. High priority should be given to the development of integrated, multidisciplinary approaches to understanding the imprint of different geophysical coastal processes on the present-day RSL changes. Assessment of coastal vulnerability, in order to take appropriate measures to protect populations, can only be determined if the RSL threshold, and even more its uncertainty, are properly estimated.

Acknowledgements: This work was funded by the Belmont Forum project BAND-AID (ANR13-JCLI-0002, http://Belmont-BanDAiD.org or http://Belmont-SeaLevel.org). It was also supported by the French research agency (Agence Nationale de la Recherche; ANR) under the STORISK project (NR-15-CE03-0003). The authors are grateful to A. Cazenave for helpful insights on the tropical sea level and G. Wöppelmann for his useful comments on the last version of the manuscript. We thank the PSMSL, ESA-CCI and SONEL teams for making tide gauge records, altimetric and GPS data, as well as corrections and accuracies, quickly and easily available for the community. We acknowledge B. Meyssignac, from LEGOS/CNES, for supplying the past sea level reconstruction dataset. 

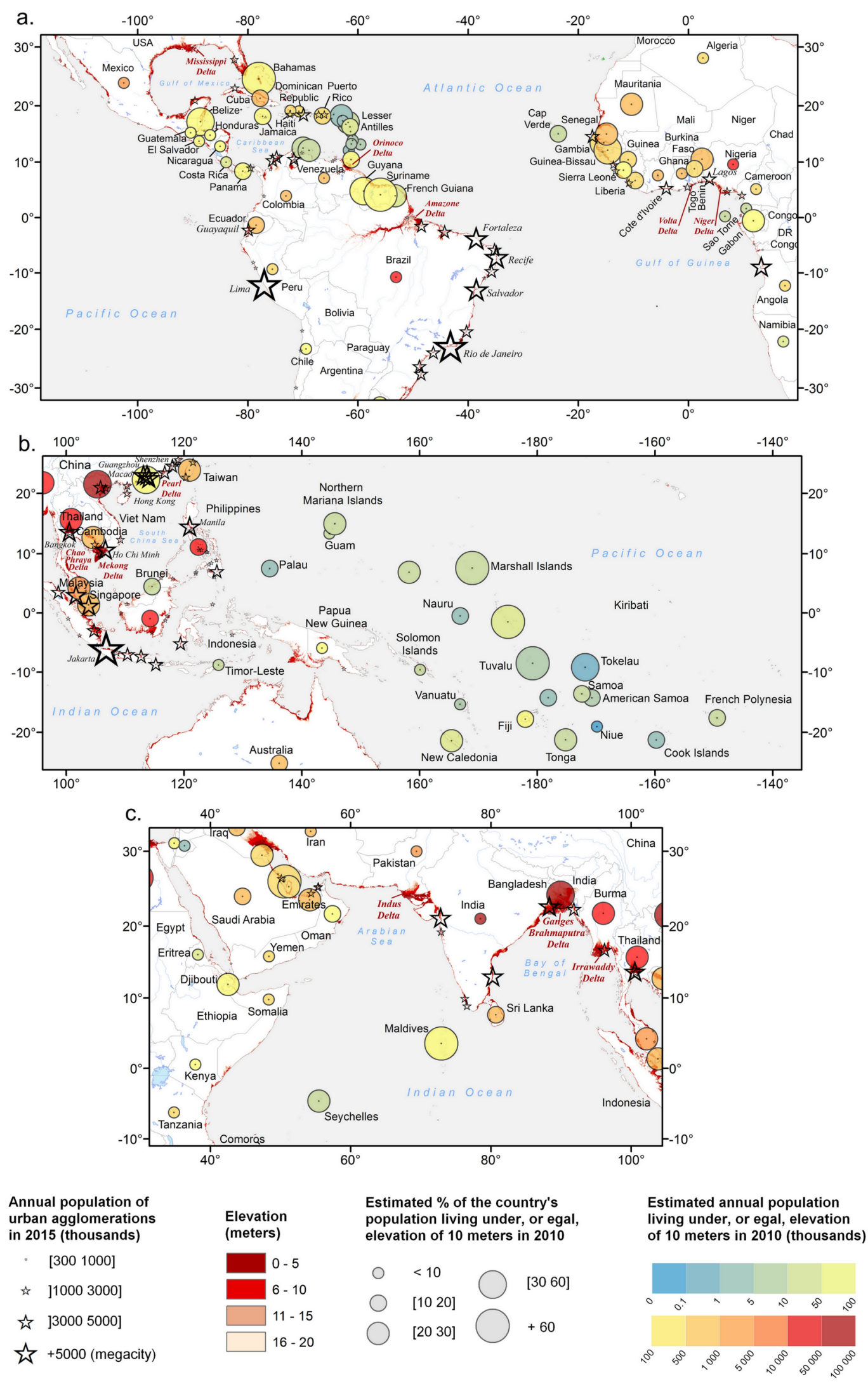

Figure 4.1: Map of the sub regions between $30^{\circ} \mathrm{N}$ to $30^{\circ} \mathrm{S}$ included in this global literature review. Annual estimated Population of Urban Agglomerations with 300,000 Inhabitants or more in 2014 (from the UN World Urbanization Prospects 2014, https://esa.un.org/unpd/wup/cd-Rom/), located, in whole or in part, in contiguous coastal elevations less than or equal to 10 meters in 2016. The global digital elevation model GTOPO30 (https://lta.cr.usgs.gov/GTOPO30) is used to map elevation less than 20 meters. 

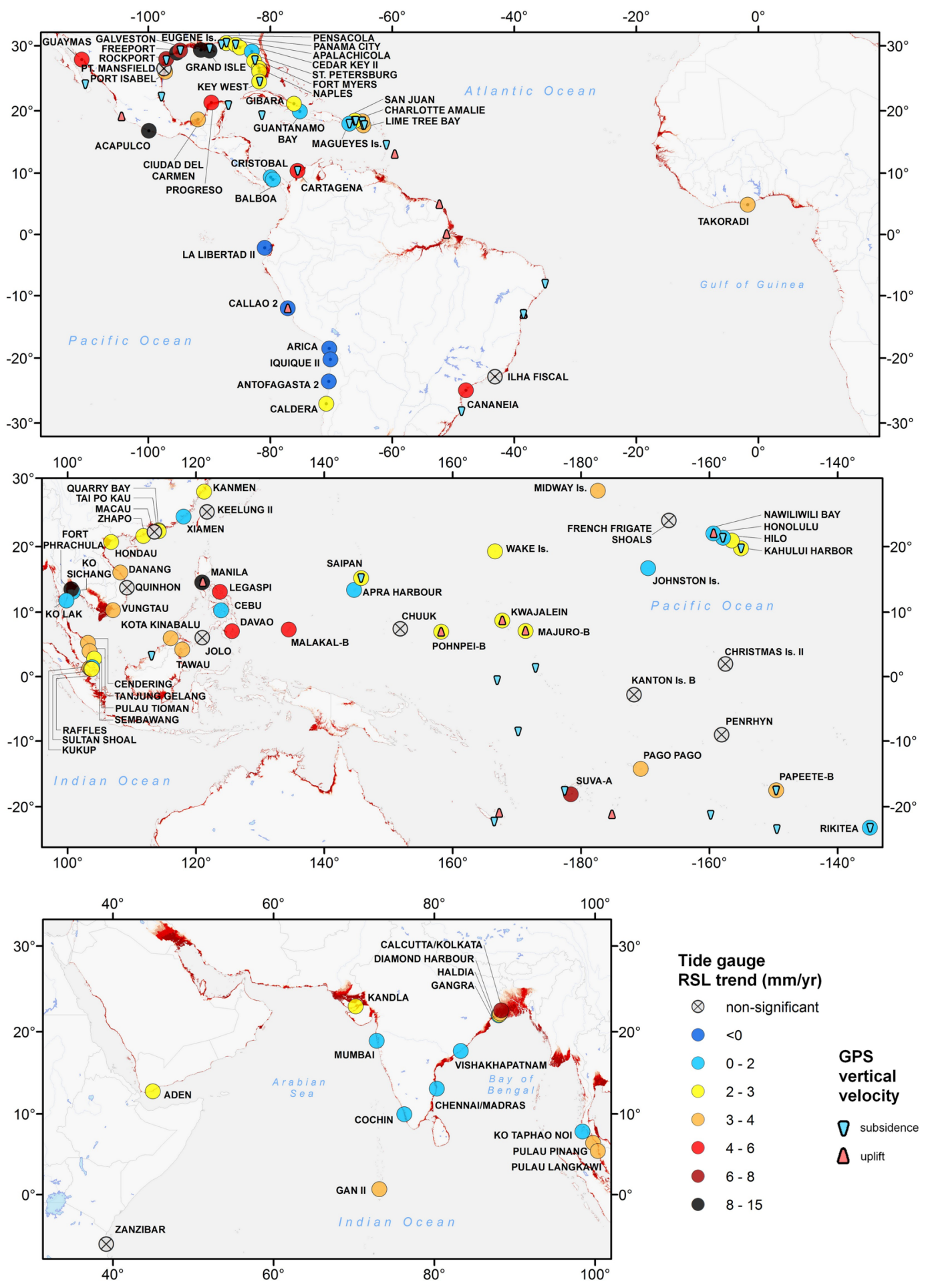

Figure 4.2: Geographic distribution of the tide gauge records, and their linear trends ( $\mathrm{mm} / \mathrm{yr}$ ), available from the RLR PSMSL dataset and GPS stations from ULR6 SONEL database. 


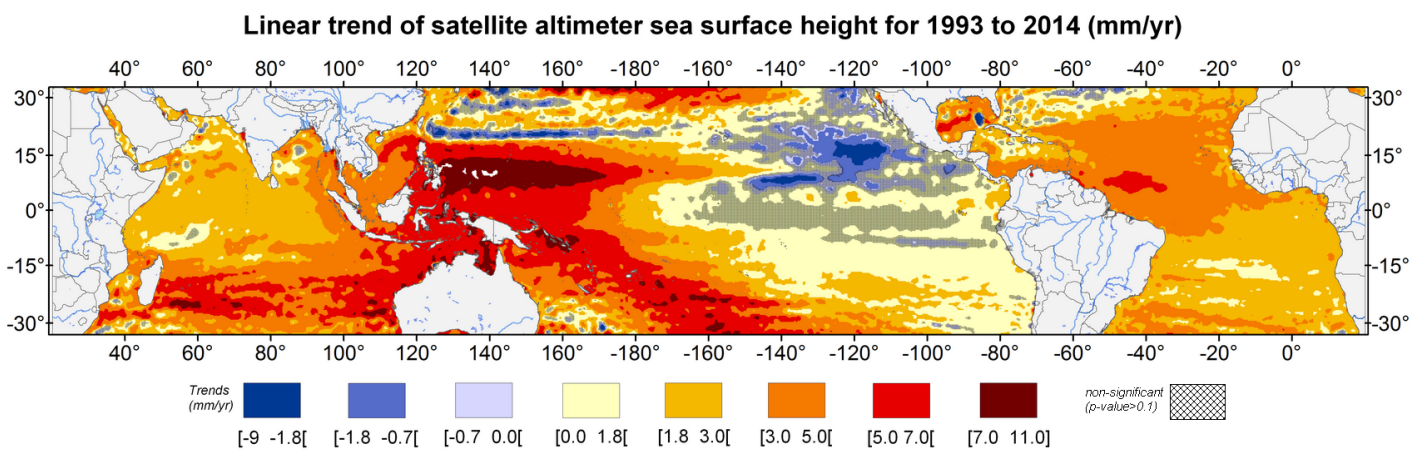

$95 \%$ margin of error for the linear trend $(\mathrm{mm} / \mathrm{yr})$

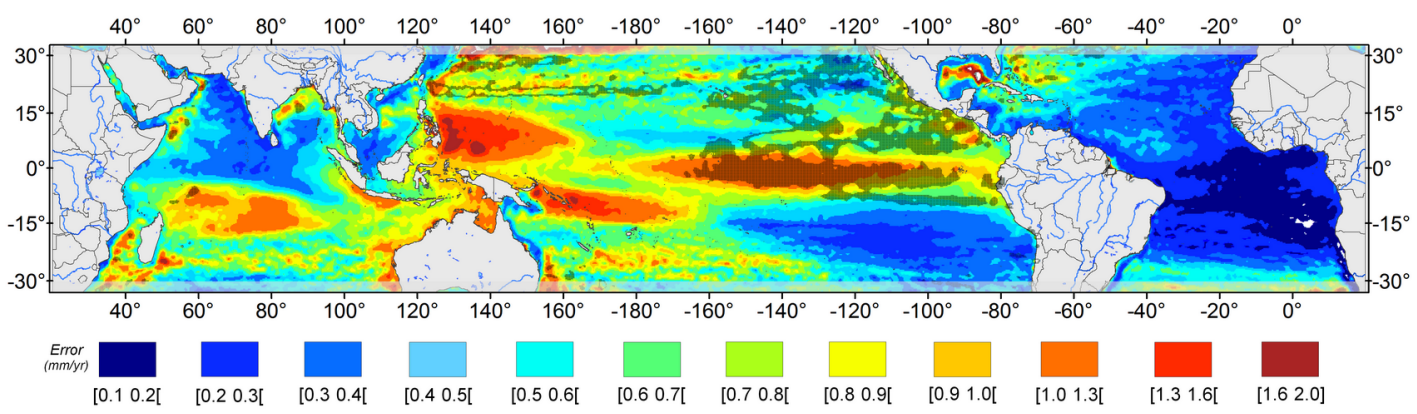

1051 Figure 4.3: (a) Geographic distribution of sea surface height linear trends (mm/yr) for 1993 to 2014 based on 1052 satellite altimetry. Shaded area represents non-significant trends ( $p$-value $>0.1$ ). (b) $95 \%$ margin of error for the 1053 linear regression equation $(\mathrm{mm} / \mathrm{yr})$.
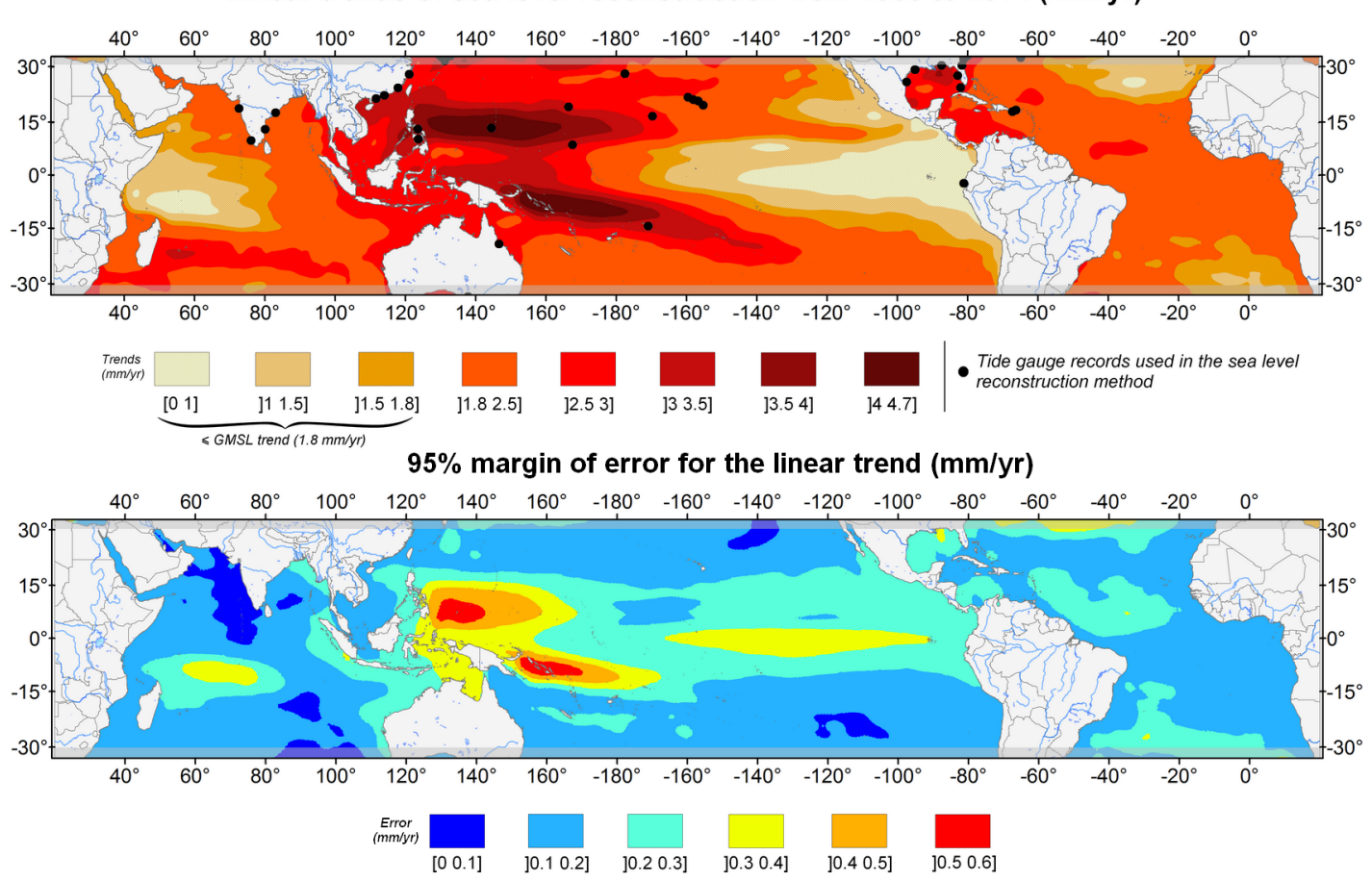

Figure 4.4: (a) Geographic distribution of sea surface height linear trends (mm/yr) for 1960 to 2014 based on sea level reconstruction in the past. Shaded area represents non-significant trends ( $\mathrm{p}$-value $>0.1$ ). Black dots represent $(\mathrm{mm} / \mathrm{yr})$ 
Table 4.1: Atlantic - Eastern South America

Locations, time spans and trends of RLR PSMSL tide gauges and SONEL GPS stations. Error corresponds to $95 \%$ margin of error for the linear trend. The symbol -.. corresponds to non-significant trend (p-value $>0.1$ ).

\begin{tabular}{|c|c|c|c|c|c|c|c|c|}
\hline COUNTRY & ID & NAME & LAT & LON & DATE & $\begin{array}{c}\text { LENGTH } \\
\text { (year) }\end{array}$ & $\begin{array}{c}\text { RSL TREND } \\
(\mathrm{mm} / \mathrm{yr})\end{array}$ & $\begin{array}{l}\text { ERROR } \\
(\mathrm{mm} / \mathrm{yr})\end{array}$ \\
\hline$\overline{\text { Brazil }}$ & 726 & CANANEIA & -25.02 & -47.93 & $1955-2004$ & 50 & 4.1 & 0.7 \\
\hline Brazil & 1032 & ILHA FISCAL & -22.90 & -43.17 & 1971-2013 & 43 & --- & --- \\
\hline
\end{tabular}

\section{GPS - ULR6 from SONEL}

\begin{tabular}{|c|c|c|c|c|c|c|c|c|c|}
\hline Country & ID & LAT & LON & DATE & $\begin{array}{c}\text { LENGTH } \\
\text { (year) }\end{array}$ & TIDE GAUGE & DISTANCE & $\begin{array}{c}\text { VERTICAL } \\
\text { VELOCITY }(\mathrm{mm} / \mathrm{yr})\end{array}$ & $\begin{array}{l}\text { ERROR } \\
(\mathrm{mm} / \mathrm{yr})\end{array}$ \\
\hline French Guiana & CAYN & 4.95 & -52.30 & $2005-2013$ & 9 & Cayenne & $11 \mathrm{~km}$ & 1.0 & 1.0 \\
\hline Brazil & MAPA & 0.05 & -51.10 & $2003-2013$ & 11 & Santana & $14 \mathrm{~km}$ & 1.0 & 0.4 \\
\hline Brazil & RECF & -8.05 & -34.95 & $1999-2013$ & 15 & Recife & $9 \mathrm{~km}$ & -2.4 & 0.3 \\
\hline Brazil & SAVO & -12.93 & -38.43 & $2007-2013$ & 7 & Salvador & $10 \mathrm{~km}$ & 0.4 & 0.4 \\
\hline Brazil & SSA1 & -12.98 & -38.52 & $2007-2013$ & 7 & Salvador & $150 \mathrm{~m}$ & -0.5 & 0.4 \\
\hline Brazil & SALV & -13.00 & -38.51 & $1999-2008$ & 10 & Salvador & $4 \mathrm{~km}$ & 0.2 & 0.4 \\
\hline Brazil & NEIA & -25.02 & -47.92 & $2002-2013$ & 12 & Cananeia & $10 \mathrm{~m}$ & 0.0 & 0.3 \\
\hline Drazit & IMBT & & 21,02 & & & , & & & \\
\hline
\end{tabular}

1060

Table 4.2: Atlantic - Caribbean Sea

Locations, time spans and trends of RLR PSMSL tide gauges and SONEL GPS stations. Error corresponds to 95\% margin of error for the linear trend. The symbol --corresponds to nonsignificant trend (p-value $>0.1)$

\begin{tabular}{lcccccccc}
\multicolumn{2}{l}{ Tide gauge from PSMSL } \\
COUNTRY & ID & NAME & LAT & LON & DATE & LENGTH (year) & $\begin{array}{c}\text { RSL TREND } \\
(\mathbf{m m} / \mathbf{y r})\end{array}$ & $\begin{array}{c}\text { ERROR } \\
(\mathbf{m m} / \mathbf{y r})\end{array}$ \\
\hline Colombia & 572 & CARTAGENA & 10.40 & -75.55 & $1949-1992$ & 44 & 5.2 & 0.5 \\
Panama & 169 & CRISTOBAL & 9.35 & -79.92 & $1909-1979$ & 71 & 1.4 & 0.3 \\
Virgin Is. US & 1447 & LIME TREE BAY & 17.69 & -64.75 & $1984-2015$ & 32 & 3.1 & 1.0 \\
Virgin Is. US & 1393 & CHARLOTTE AMALIE & 18.34 & -64.92 & $1985-2015$ & 31 & 3.3 & 1.2 \\
Porto Rico & 1001 & SAN JUAN & 18.46 & -66.12 & $1963-2015$ & 53 & 2.1 & 0.5 \\
Porto Rico & 759 & MAGUEYES ISLAND & 17.97 & -67.05 & $1955-2015$ & 61 & 1.7 & 0.4 \\
Cuba & 418 & GUANTANAMO BAY & 19.91 & -75.15 & $1938-1971$ & 34 & 1.8 & 0.8 \\
Cuba & 563 & GIBARA & 21.11 & -76.13 & $1976-2014$ & 39 & 2.0 & 1.0
\end{tabular}

GPS - ULR6 from SONEL

\begin{tabular}{|c|c|c|c|c|c|c|c|c|c|}
\hline Country & ID & LAT & LON & DATE & LENGTH (year) & TIDE GAUGE & DISTANCE & $\begin{array}{c}\text { VERTICAL } \\
\text { VELOCITY }(\mathrm{mm} / \mathrm{yr})\end{array}$ & $\begin{array}{l}\text { ERROR } \\
(\mathrm{mm} / \mathrm{yr})\end{array}$ \\
\hline Mexico & UNPM & 20.87 & -86.87 & $2007-2013$ & 7 & Puerto Morelos & $146 \mathrm{~m}$ & -1.9 & 0.4 \\
\hline Colombia & CART & 10.39 & -75.53 & $2000-2008$ & 9 & Cartagena & $2 \mathrm{~km}$ & -2.2 & 0.5 \\
\hline Cayman Is. & GCGT & 19.29 & -81.38 & 2005-2011 & 7 & South Sound & $7 \mathrm{~km}$ & -1.4 & 0.2 \\
\hline Puerto Rico & BYSP & 18.40 & -66.16 & 2008-2013 & 6 & San Juan & $9 \mathrm{~km}$ & -1.3 & 0.8 \\
\hline Puerto Rico & PRMI & 17.97 & -67.05 & 2006-2013 & 8 & Magueyes & $500 \mathrm{~m}$ & -0.4 & 0.2 \\
\hline Puerto Rico & MAYZ & 18.22 & -67.16 & 2010-2013 & 4 & Mayaguez & $2 \mathrm{~m}$ & --- & -..- \\
\hline Puerto Rico & zSU1 & 18.43 & -65.99 & 2003-2011 & 9 & San Juan & $10 \mathrm{~km}$ & -1.1 & 0.3 \\
\hline Virgin Is. US & STVI & 18.34 & -64.97 & 2008-2013 & 6 & Charlotte & $6 \mathrm{~km}$ & -1.6 & 0.5 \\
\hline Virgin Is. US & VITH & 18.33 & -64.92 & $2006-2013$ & 8 & Charlotte & $5 \mathrm{~km}$ & -1.3 & 0.3 \\
\hline Virgin Is. US & VIKH & 17.71 & -64.80 & $2006-2013$ & 8 & Lime tree bay & $4 \mathrm{~km}$ & -2.9 & 0.3 \\
\hline Virgin Is. US & CR01 & 17.76 & -64.58 & $1994-2013$ & 20 & Christiansted & $13 \mathrm{~km}$ & -1.1 & 0.4 \\
\hline French West Indies & ABMF & 16.26 & -61.52 & 2008-2013 & 6 & Pointe-à-Pitre & $4 \mathrm{~km}$ & --- & -.- \\
\hline French West Indies & LMMF & 14.59 & -60.99 & 2008-2013 & 6 & Fort de France & $7 \mathrm{~km}$ & -3.6 & 0.5 \\
\hline Barbados & BDOS & 13.09 & -59.61 & 2004-2013 & 10 & Bridgetown & $3 \mathrm{~km}$ & 0.4 & 0.5 \\
\hline
\end{tabular}

1061

1062

1063 
Table 4.3: Atlantic - Gulf of Mexico

Locations, time spans and trends of RLR PSMSL tide gauges and SONEL GPS stations. Error corresponds to $95 \%$ margin of error for the linear trend. The symbol --- corresponds to nonsignificant trend (p-value $>0.1$ )

\begin{tabular}{|c|c|c|c|c|c|c|c|c|}
\hline COUNTRY & ID & NAME & LAT & LON & DATE & $\begin{array}{c}\text { LENGTH } \\
\text { (year) }\end{array}$ & $\begin{array}{c}\text { RSL TREND } \\
(\mathrm{mm} / \mathrm{yr})\end{array}$ & $\begin{array}{l}\text { ERROR } \\
(\mathrm{mm} / \mathrm{yr})\end{array}$ \\
\hline Mexico & 690 & PROGRESO & 21.30 & -89.67 & $1952-1984$ & 33 & 5.2 & 1.0 \\
\hline Mexico & 796 & CIUDAD DEL CARMEN & 18.63 & -91.85 & $1957-1987$ & 31 & 3.6 & 1.2 \\
\hline USA & 497 & PORT ISABEL & 26.06 & -97.22 & $1945-2015$ & 71 & 3.9 & 0.4 \\
\hline USA & 1038 & PORT MANSFIELD & 26.55 & -97.42 & 1964-1995 & 32 & --- & --- \\
\hline USA & 538 & ROCKPORT & 28.02 & -97.05 & $1964-2014$ & 51 & 6.1 & 0.8 \\
\hline USA & 725 & FREEPORT & 28.95 & -95.31 & $1955-2007$ & 53 & 8.8 & 1.2 \\
\hline USA & 828 & GALVESTON I & 29.29 & -94.79 & $1958-2010$ & 53 & 6.7 & 0.8 \\
\hline USA & 161 & GALVESTON II & 29.31 & -94.79 & $1909-2015$ & 107 & 6.4 & 0.3 \\
\hline USA & 440 & EUGENE ISLAND & 29.37 & -91.39 & 1940-1974 & 35 & 9.7 & 1.5 \\
\hline USA & 526 & GRAND ISLE & 29.26 & -89.96 & $1947-2015$ & 69 & 9.0 & 0.5 \\
\hline USA & 246 & PENSACOLA & 30.40 & -87.21 & 1924-2015 & 92 & 2.2 & 0.3 \\
\hline USA & 1641 & PANAMA CITY & 30.15 & -85.67 & $1985-2015$ & 31 & 3.0 & 1.1 \\
\hline USA & 1193 & APALACHICOLA & 29.73 & -84.98 & $1968-2015$ & 48 & 2.1 & 0.8 \\
\hline USA & 428 & CEDAR KEY II & 29.14 & -83.03 & $1939-2015$ & 77 & 1.8 & 0.3 \\
\hline USA & 520 & ST. PETERSBURG & 27.76 & -82.63 & $1947-2015$ & 69 & 2.7 & 0.3 \\
\hline USA & 1106 & FORT MYERS & 26.65 & -81.87 & $1966-2015$ & 50 & 2.9 & 0.6 \\
\hline USA & 1107 & NAPLES & 26.13 & -81.81 & 1966-2015 & 50 & 2.5 & 0.6 \\
\hline USA & 188 & KEY WEST & 24.56 & -81.81 & $1913-2015$ & 103 & 2.4 & 0.2 \\
\hline
\end{tabular}

1065

GPS - ULR6 from SONEL

\begin{tabular}{|c|c|c|c|c|c|c|c|c|c|}
\hline Country & ID & LAT & LON & DATE & $\begin{array}{c}\text { LENGTH } \\
\text { (year) }\end{array}$ & TIDE GAUGE & DISTANCE & $\begin{array}{c}\text { VERTICAL } \\
\text { VELOCITY }(\mathrm{mm} / \mathrm{yr})\end{array}$ & $\begin{array}{l}\text { ERROR } \\
(\mathrm{mm} / \mathrm{yr})\end{array}$ \\
\hline Mexico & TAMP & 22.23 & -97.86 & $2007-2013$ & 7 & Ciudad Madero & $7 \mathrm{~km}$ & -0.8 & 0.4 \\
\hline USA & ARP3 & 27.83 & -97.06 & $1995-2006$ & 12 & Port Aransas & $1 \mathrm{~km}$ & -1.3 & 0.4 \\
\hline USA & TXGA & 29.33 & -94.77 & 2005-2013 & 9 & Galveston & $3 \mathrm{~km}$ & -3.4 & 0.8 \\
\hline USA & GAL1 & 29.33 & -94.74 & $1995-2003$ & 9 & Galveston & $6 \mathrm{~km}$ & -4.6 & 0.8 \\
\hline USA & GRIS & 29.62 & -89.96 & 2004-2013 & 10 & Grand Isle & $100 \mathrm{~m}$ & -6.5 & 0.5 \\
\hline USA & MOB1 & 30.23 & -88.02 & 1996-2009 & 14 & Dauphin Is. & $6 \mathrm{~km}$ & -3.1 & 0.4 \\
\hline USA & PCLA & 30.47 & -87.19 & 2004-2013 & 10 & Pensacola & $8 \mathrm{~km}$ & -0.4 & 0.4 \\
\hline USA & PNCY & 30.20 & -85.68 & 2001-2010 & 10 & Panama City & $6 \mathrm{~km}$ & -0.2 & 0.4 \\
\hline USA & MCD5 & 27.85 & -82.53 & 2007-2013 & 7 & St Petersburg & $14 \mathrm{~km}$ & -1.6 & 0.4 \\
\hline USA & MCD1 & 27.85 & -82.53 & 2001-2007 & 7 & St Petersburg & $13 \mathrm{~km}$ & -0.3 & 0.7 \\
\hline USA & KWST & 24.55 & -81.75 & 2002-2013 & 12 & Key West & $5 \mathrm{~km}$ & -1.1 & 0.4 \\
\hline USA & CHIN & 24.55 & -81.81 & $2007-2013$ & 7 & Key West & $400 \mathrm{~m}$ & --- & --- \\
\hline
\end{tabular}

Table 4.4: Pacific - Central America and South America

Locations, time spans and trends of RLR PSMSL tide gauges and SONEL GPS stations. Error corresponds to $95 \%$ margin of error for the linear trend. The symbol ---corresponds to nonsignificant trend (p-value $>0.1$ ).

\begin{tabular}{|c|c|c|c|c|c|c|c|c|}
\hline COUNTRY & ID & NAME & LAT & LON & DATE & $\begin{array}{c}\text { LENGTH } \\
\text { (year) }\end{array}$ & $\begin{array}{l}\text { RSL TREND } \\
(\mathrm{mm} / \mathrm{yr})\end{array}$ & $\begin{array}{l}\text { ERROR } \\
(\mathrm{mm} / \mathrm{yr})\end{array}$ \\
\hline Mexico & 693 & GUAYMAS & 27.92 & -110.90 & 1952-1989 & 38 & 4.4 & 1.4 \\
\hline Mexico & 686 & ACAPULCO & 16.83 & -99.92 & $1967-2000$ & 34 & 8.4 & 3.0 \\
\hline Panama & 163 & BALBOA & 8.97 & -79.57 & 1908-2015 & 108 & 1.5 & 0.2 \\
\hline Ecuador & 544 & LA LIBERTAD II & -2.20 & -80.92 & $1950-2002$ & 53 & -1.3 & 1.0 \\
\hline Peru & 1274 & CALLAO 2 & -12.05 & -77.15 & $1970-2014$ & 45 & -0.3 & 1.2 \\
\hline Chile & 618 & ARICA & -18.47 & -70.33 & 1952-1991 & 40 & -0.7 & 1.5 \\
\hline Chile & 2261 & IQUIQUE II & -20.20 & -70.15 & $1986-2015$ & 30 & -1.1 & 1.8 \\
\hline Chile & 510 & ANTOFAGASTA 2 & -23.65 & -70.40 & $1946-2015$ & 70 & -0.8 & 0.5 \\
\hline Chile & 619 & CALDERA & -27.07 & -70.83 & 1951-1991 & 41 & 2.8 & 0.9 \\
\hline
\end{tabular}

\begin{tabular}{|c|c|c|c|c|c|c|c|c|c|}
\hline Country & ID & LAT & LON & DATE & $\begin{array}{c}\text { LENGTH } \\
\text { (year) }\end{array}$ & TIDE GAUGE & DISTANCE & $\begin{array}{c}\text { VERTICAL } \\
\text { VELOCITY }(\mathrm{mm} / \mathrm{yr})\end{array}$ & $\begin{array}{l}\text { ERROR } \\
(\mathrm{mm} / \mathrm{yr})\end{array}$ \\
\hline Mexico & SLCR & 16.17 & -95.20 & $2008-2012$ & 5 & Salina Cruz & $1 \mathrm{~m}$ & --- & --- \\
\hline Mexico & LPAZ & 24.14 & -110.32 & 2006-2012 & 7 & La Paz & $3 \mathrm{~km}$ & -1.1 & 0.3 \\
\hline Mexico & UCOM & 19.12 & -104.40 & 2007-2012 & 6 & Manzanillo & $12 \mathrm{~km}$ & 0.7 & 0.6 \\
\hline Mexico & ACYA & 16.84 & -99.90 & 2004-2012 & 9 & Acapulco & $1 \mathrm{~m}$ & --- & --- \\
\hline Peru & ALL & -12.06 & 15 & 2009-2013 & 5 & Callao & $1 \mathrm{~km}$ & 2.0 & 0.6 \\
\hline
\end{tabular}


Table 4.5: Pacific - Southeast Asia

Locations, time spans and trends of RLR PSMSL tide gauges and SONEL GPS stations. Error corresponds to $95 \%$ margin of error for the linear trend. The symbol ---corresponds to nonsignificant trend (p-value $>0.1$ ).

\begin{tabular}{|c|c|c|c|c|c|c|c|c|}
\hline COUNTRY & ID & NAME & LAT & LON & DATE & $\begin{array}{c}\text { LENGTH } \\
\text { (year) }\end{array}$ & $\begin{array}{c}\text { RSL TREND } \\
(\mathrm{mm} / \mathrm{yr})\end{array}$ & $\begin{array}{l}\text { ERROR } \\
(\mathrm{mm} / \mathrm{yr})\end{array}$ \\
\hline VietNam & 841 & HONDAU & 20.67 & 106.80 & $1957-2013$ & 57 & 2.1 & 0.6 \\
\hline VietNam & 1449 & QUINHON & 13.77 & 109.25 & $1977-2013$ & 37 & --- & --- \\
\hline VietNam & 1475 & DANANG & 16.10 & 108.22 & $1978-2013$ & 36 & 3.2 & 1.0 \\
\hline VietNam & 1495 & VUNGTAU & 10.33 & 107.07 & 1979-2013 & 35 & 3.6 & 1.4 \\
\hline Thailand & 449 & KO SICHANG & 13.15 & 100.82 & 1940-2002 & 63 & 0.8 & 0.5 \\
\hline Thailand & 444 & FORT PHRACHULA & 13.55 & 100.58 & $1940-2015$ & 76 & 14.7 & 0.9 \\
\hline Thailand & 174 & KO LAK & 11.80 & 99.82 & $1940-2015$ & 76 & 0.8 & 0.5 \\
\hline Malaysia & 1592 & CENDERING & 5.27 & 103.19 & 1985-2014 & 30 & 3.3 & 1.1 \\
\hline Malaysia & 1589 & TANJUNG GELANG & 3.98 & 103.43 & $1984-2015$ & 32 & 3.3 & 0.9 \\
\hline Malaysia & 1678 & PULAU TIOMAN & 2.81 & 104.14 & 1986-2015 & 30 & 2.8 & 1.2 \\
\hline Malaysia & 1677 & KUKUP & 1.33 & 103.44 & 1986-2015 & 30 & 3.6 & 1.3 \\
\hline Singapore & 724 & SEMBAWANG & 1.47 & 103.83 & $1972-2015$ & 44 & 1.8 & 0.7 \\
\hline Singapore & 1248 & SULTAN SHOAL & 1.23 & 103.65 & $1972-2015$ & 44 & 2.9 & 0.9 \\
\hline Singapore & 1351 & RAFFLES & 1.17 & 103.75 & $1980-2015$ & 36 & 2.7 & 1.1 \\
\hline Malaysia & 1733 & KOTA KINABALU & 5.98 & 116.07 & $1988-2015$ & 28 & 3.9 & 1.9 \\
\hline Malaysia & 1734 & TAWAU & 4.23 & 117.88 & $1988-2015$ & 28 & 4.0 & 2.8 \\
\hline Philippines & 260 & JOLO. SULU & 6.07 & 121.00 & 1948-1994 & 47 & --- & --- \\
\hline Philippines & 145 & MANILA & 14.58 & 120.97 & 1948-2015 & 68 & 13.8 & 0.7 \\
\hline Philippines & 394 & CEBU & 10.30 & 123.92 & $1948-2015$ & 68 & 0.9 & 0.7 \\
\hline Philippines & 522 & LEGASPI & 13.15 & 123.75 & 1949-2009 & 61 & 5.5 & 0.7 \\
\hline Philippines & 537 & DAVAO & 7.08 & 125.63 & 1949-1992 & 44 & 5.3 & 1.2 \\
\hline Tawain & 545 & KEELUNG II & 25.13 & 121.73 & 1956-1994 & 39 & --- & --- \\
\hline China & 934 & KANMEN & 28.08 & 121.28 & $1959-2015$ & 57 & 2.2 & 0.4 \\
\hline China & 727 & XIAMEN & 24.45 & 118.07 & $1954-2003$ & 50 & 1.1 & 0.8 \\
\hline China & 933 & ZHAPO & 21.58 & 111.82 & $1959-2015$ & 57 & 2.2 & 0.5 \\
\hline Hong Kong & 1034 & TAI PO KAU & 22.44 & 114.18 & 1963-2015 & 53 & 3.0 & 0.8 \\
\hline Hong Kong & 333 & NORTH POINT & 22.30 & 114.20 & $1950-1985$ & 36 & --- & --- \\
\hline Hong Kong & 1674 & QUARRY BAY & 22.29 & 114.21 & $1986-2015$ & 30 & 2.8 & 1.7 \\
\hline Macao & 269 & MACAU & 22.20 & 113.55 & $1925-1982$ & 58 & --- & -.-- \\
\hline
\end{tabular}

\section{GPS - ULR6 from SONEL}

\begin{tabular}{|c|c|c|c|c|c|c|c|c|c|}
\hline Country & ID & LAT & LON & DATE & $\begin{array}{c}\text { LENGTH } \\
\text { (year) }\end{array}$ & TIDE GAUGE & DISTANCE & $\begin{array}{c}\text { VERTICAL } \\
\text { VELOCITY }(\mathrm{mm} / \mathrm{yr}) \\
\end{array}$ & $\begin{array}{l}\text { ERROR } \\
(\mathrm{mm} / \mathrm{yr}) \\
\end{array}$ \\
\hline Malaysia & GETI & 6.22 & 102.11 & 1998-2002 & 5 & Geting & $5 \mathrm{~m}$ & --- & --- \\
\hline Malaysia & KUAL & 5.32 & 103.14 & $2007-2013$ & 7 & Cendering & $8 \mathrm{~km}$ & --- & --- \\
\hline Malaysia & UMSS & 6.04 & 116.11 & $2007-2013$ & 7 & Kota Kinabalu & $8 \mathrm{~km}$ & --. & --- \\
\hline Malaysia & JUML & 2.21 & 102.26 & 2004-2013 & 10 & Tanjung Keling & $11 \mathrm{~km}$ & --- & --- \\
\hline Malaysia & BIN1 & 3.24 & 113.09 & 2007-2011 & 5 & Bintulu & $4 \mathrm{~km}$ & -3.2 & 0.5 \\
\hline Singapore & NTUS & 1.35 & 103.68 & $1997-2013$ & 17 & Jurong & $7 \mathrm{~km}$ & --- & --- \\
\hline Philippines & PIMO & 14.64 & 121.08 & 1998-2010 & 13 & Manila & $13 \mathrm{~km}$ & 2.7 & 0.6 \\
\hline
\end{tabular}


Table 4.6: Pacific - Western Tropical Pacific Islands

Locations, time spans and trends of RLR PSMSL tide gauges and SONEL GPS stations. Error corresponds to 95\% margin of error for the linear trend. The symbol ---corresponds to non-significant trend $(p-$ value $>0.1)$.

Tide gauge from PSMSL

\begin{tabular}{|c|c|c|c|c|c|c|c|c|}
\hline COUNTRY & ID & NAME & LAT & LON & DATE & $\begin{array}{c}\text { LENGTH } \\
\text { (year) }\end{array}$ & $\begin{array}{c}\text { RSL TREND } \\
(\mathrm{mm} / \mathrm{yr})\end{array}$ & $\begin{array}{l}\text { ERROR } \\
(\mathrm{mm} / \mathrm{yr})\end{array}$ \\
\hline Palau & 1252 & MALAKAL-B & 7,33 & 134,47 & 1976-2014 & 39 & 4,1 & 2,5 \\
\hline Guam & 540 & APRA HARBOUR & 13,44 & 144,65 & 1948-2015 & 68 & 1,8 & 0,9 \\
\hline Northern Mariana Is. & 1474 & SAIPAN & 15,23 & 145,75 & $1979-2014$ & 36 & 2,8 & 2,1 \\
\hline Micronesia & 528 & CHUUK & 7,45 & 151,85 & 1953-1986 & 34 & -..- & ... \\
\hline Micronesia & 1370 & POHNPEI-B & 6,98 & 158,23 & 1976-2014 & 39 & 2,6 & 1,7 \\
\hline Marshall Is. & 595 & WAKE ISLAND & 19,29 & 166,62 & $1951-2015$ & 65 & 2 & 0,5 \\
\hline Marshall Is. & 513 & KWAJALEIN & 8,73 & 167,74 & $1947-2015$ & 69 & 2,2 & 0,7 \\
\hline Marshall Is. & 1217 & MAJURO-B & 7,10 & 171,37 & 1969-2001 & 33 & 3 & 1,8 \\
\hline Fiji & 1327 & SUVA-A & $-18,14$ & 178,42 & $1988-2015$ & 28 & 6,7 & 1,9 \\
\hline French Polynesia & 1253 & RIKITEA & $-23,12$ & $-134,97$ & $1970-2014$ & 45 & 1,7 & 0,6 \\
\hline French Polynesia & 1397 & PAPEETE-B & $-17,53$ & $-149,57$ & 1970-2014 & 45 & 3,3 & 0,8 \\
\hline USA & 300 & HILO & 19,73 & $-155,06$ & $1947-2015$ & 69 & 2,9 & 0,5 \\
\hline USA & 521 & KAHULUI HARBOR & 20,90 & $-156,48$ & $1951-2015$ & 65 & 1,9 & 0,5 \\
\hline USA & 155 & HONOLULU & 21,31 & $-157,87$ & 1905-2015 & 111 & 1,4 & 0,2 \\
\hline USA & 756 & NAWILIWILI BAY & 21,95 & $-159,36$ & $1955-2015$ & 61 & 1,5 & 0,5 \\
\hline USA & 1372 & FRENCH FRIGATE SHOALS & 23,87 & $-166,28$ & 1975-2005 & 31 & -.- & -.- \\
\hline USA & 598 & JOHNSTON ISLAND & 16,74 & $-169,53$ & 1950-2002 & 53 & 0,8 & 0,7 \\
\hline USA & 523 & MIDWAY ISLAND & 28,21 & $-177,36$ & 1982-2015 & 34 & 3,8 & 1,2 \\
\hline Cook Is. & 1450 & PENRHYN & $-9,02$ & $-158,07$ & 1978-2014 & 37 & -.- & -.- \\
\hline American Samoa & 539 & PAGO PAGO & $-14,28$ & $-170,69$ & $1949-2015$ & 67 & 3,2 & 0,7 \\
\hline Kiribati & 1329 & KANTON ISLAND-B & $-2,82$ & $-171,72$ & 1973-2011 & 39 & --- & -.- \\
\hline Kiribati & 1371 & CHRISTMAS ISLAND II & 1,98 & $-157,48$ & 1981-2014 & 34 & --. & -.- \\
\hline
\end{tabular}

GPS - ULR6 from SONEL

\begin{tabular}{|c|c|c|c|c|c|c|c|c|c|}
\hline Country & ID & LAT & LON & DATE & $\begin{array}{c}\text { LENGTH } \\
\text { (year) }\end{array}$ & TIDE GAUGE & DISTANCE & $\begin{array}{c}\text { VERTICAL } \\
\text { VELOCITY }(\mathrm{mm} / \mathrm{yr}) \\
\end{array}$ & $\begin{array}{l}\text { ERROR } \\
(\mathrm{mm} / \mathrm{yr})\end{array}$ \\
\hline Cook Is. & CKIS & $-21,20$ & $-159,80$ & 2002-2013 & 12 & Rarotonga B & $3 \mathrm{~km}$ & $-0,5$ & 0,4 \\
\hline Fiji & LAUT & $-17,61$ & 177,45 & 2002-2013 & 12 & Lautoka & $1 \mathrm{~km}$ & $-1,2$ & 0,3 \\
\hline French Loyalty Is. & LPIL & $-20,92$ & 167,26 & 1997-2013 & 17 & Lifou & $2 \mathrm{~km}$ & 0,2 & 0,5 \\
\hline French Polynesia & GAMB & $-23,13$ & $-134,96$ & $2000-2003$ & 4 & Rikitea & $900 \mathrm{~m}$ & -1 & 0,4 \\
\hline French Polynesia & PAPE & $-17,53$ & $-149,57$ & 2003-2013 & 11 & Papeete & $1 \mathrm{~m}$ & $-1,9$ & 0,2 \\
\hline French Polynesia & FAA1, TAH2 & $-17,55$ & $-149,61$ & 2007-2011 & 5 & Papeete & $6 \mathrm{~km}$ & $-1,8$ & 0,5 \\
\hline Marshall Is. & MAJU & 7,12 & 171,36 & 2007-2013 & 7 & Majuro & $2 \mathrm{~km}$ & 0,8 & 0,4 \\
\hline Micronesia & POHN & 6,96 & 158,21 & 2003-2013 & 11 & Pohnpei & $3 \mathrm{~km}$ & 0,8 & 0,4 \\
\hline Palau & PALA & 7,34 & 134,48 & 1996-2001 & 6 & Malakal & $3 \mathrm{~km}$ & --. & --. \\
\hline Rep. of Nauru & NAUR & $-0,55$ & 166,93 & 2003-2013 & 11 & Nauru & $3 \mathrm{~km}$ & -1 & 0,3 \\
\hline Samoa & SAMO & $-13,85$ & $-171,74$ & 2001-2013 & 13 & Apia B & $4 \mathrm{~km}$ & --. & --. \\
\hline Solomon Is. & SOLO & $-9,43$ & 159,95 & 2010-2013 & 4 & Honiara B & $1 \mathrm{~km}$ & -..- & -.- \\
\hline Tonga & TONG & $-21,14$ & $-175,18$ & 2002-2013 & 12 & Nuku'Alofa B & $800 \mathrm{~m}$ & 3 & 0,4 \\
\hline USA & $\mathrm{ZHN} 1$ & 21,31 & $-157,92$ & 2002-2013 & 12 & Honolulu & $6 \mathrm{~km}$ & $-0,6$ & 0,3 \\
\hline Vanuatu & VANU & $-17,74$ & 168,32 & 2002-2012 & 11 & Port Vila B & $1 \mathrm{~km}$ & -.- & -.- \\
\hline Tuvalu & TUVA & $-8,53$ & 170,20 & 2002-2013 & 12 & Funafuti B & $3 \mathrm{~km}$ & $-1,7$ & 0,2 \\
\hline
\end{tabular}

Table 4.7: Indian Ocean - Bay of Bengal

Locations, time spans and trends of RLR PSMSL tide gauges and SONEL GPS stations. Error corresponds to $95 \%$ margin of error for the linear trend. The symbol ---corresponds to non-significant trend (p-value $>0.1$ ).

Tide gauge from PSMSL

\begin{tabular}{|c|c|c|c|c|c|c|c|c|}
\hline COUNTRY & ID & NAME & LAT & LON & DATE & $\begin{array}{c}\text { LENGTH } \\
\text { (year) }\end{array}$ & $\begin{array}{c}\text { RSL } \\
\text { TREND } \\
(\mathrm{mm} / \mathrm{yr})\end{array}$ & $\begin{array}{l}\text { ERROR } \\
(\mathrm{mm} / \mathrm{yr})\end{array}$ \\
\hline India & 205 & CHENNAI / MADRAS & 13.10 & 80.30 & $1953-2012$ & 60 & 0.6 & 0.5 \\
\hline India & 414 & VISHAKHAPATNAM & 17.68 & 83.28 & $1937-2011$ & 75 & 0.8 & 0.5 \\
\hline India & 1369 & GANGRA & 21.95 & 88.02 & $1974-2006$ & 33 & 1.2 & 1.6 \\
\hline India & 1270 & HALDIA & 22.03 & 88.10 & $1971-2012$ & 42 & 2.8 & 0.9 \\
\hline India & 543 & DIAMOND HARBOUR & 22.20 & 88.17 & $1948-2012$ & 65 & 4 & 0.7 \\
\hline India & 369 & CALCUTTA & 22.55 & 88.30 & 1932-1999 & 68 & 7.4 & 1.3 \\
\hline Thailand & 446 & KO TAPHAO NOI & 7.83 & 98.43 & $1940-2015$ & 76 & 1.3 & 0.9 \\
\hline Malaysia & 1676 & PULAU LANGKAWI & 6.43 & 99.76 & $1986-2015$ & 30 & 3.4 & 1.9 \\
\hline Malaysia & 1595 & PULAU PINANG & 5.42 & 100.35 & $1986-2014$ & 29 & 3.9 & 1.9 \\
\hline
\end{tabular}


Table 4.8: Indian Ocean - Arabian Sea, Persian Gulf and Maldives

Locations, time spans and trends of RLR PSMSL tide gauges and SONEL GPS stations. Error corresponds to 95\% margin of error for the linear trend. The symbol ---corresponds to nonsignificant trend ( $p$-value $>0.1)$.

\begin{tabular}{lcccccccc}
\multicolumn{2}{l}{ Tide gauge from PSMSL } \\
\hline COUNTRY & ID & NAME & LAT & LON & DATE & $\begin{array}{c}\text { LENGTH } \\
(\mathbf{y e a r})\end{array}$ & $\begin{array}{c}\text { RSL TREND } \\
(\mathbf{m m} / \mathbf{y r})\end{array}$ & $\begin{array}{c}\text { ERROR } \\
(\mathbf{m m} / \mathbf{y r})\end{array}$ \\
\hline Tanzania & 1600 & ZANZIBAR & -6.15 & 39.18 & $1985-2013$ & 29 &.-- &.-- \\
Yemen & 44 & ADEN & 12.79 & 44.97 & $1916-1967$ & 52 & 2.3 & 0.5 \\
India & 596 & KANDLA & 23.02 & 70.22 & $1954-1996$ & 43 & 2.6 & 0.8 \\
India & 43 & MUMBAI / BOMBAY & 18.92 & 72.83 & $1878-1993$ & 116 & 0.7 & 0.1 \\
India & 438 & COCHIN & 9.97 & 76.27 & $1939-2007$ & 69 & 1.5 & 0.4 \\
Mauritius & 1673 & PORT LOUIS II & -20.15 & 57.50 & $1987-2016$ & 30 & 4.1 & 1.7 \\
Mauritius & 1672 & RODRIGUES Is. & -19.66 & 63.42 & $1987-2016$ & 30 & 5.9 & 2.1
\end{tabular}

GPS - ULR6 from SONEL

\begin{tabular}{|c|c|c|c|c|c|c|c|c|c|}
\hline Country & ID & LAT & LON & DATE & $\begin{array}{c}\text { LENGTH } \\
\text { (year) }\end{array}$ & TIDE GAUGE & DISTANCE & $\begin{array}{c}\text { VERTICAL } \\
\text { VELOCITY }(\mathrm{mm} / \mathrm{yr})\end{array}$ & $\begin{array}{l}\text { ERROR } \\
(\mathrm{mm} / \mathrm{yr}) \\
\end{array}$ \\
\hline Tanzan & ZNZB & -6. & 39.21 & 2010-2013 & 4 & Zanzibar & $7 \mathrm{ki}$ & --- & --- \\
\hline Mauritius & VACS & -20.30 & 57.50 & 2008-2012 & 5 & Port louis II & $15 \mathrm{~km}$ & -0.8 & 0.4 \\
\hline
\end{tabular}

References:

Abam, T. K. S. (2001), Regional hydrological research perspectives in the Niger Delta, Hydrological sciences journal, 46(1), 13-25.

Abidin, H. Z., H. Andreas, M. Gamal, I. Gumilar, M. Napitupulu, Y. Fukuda, T. Deguchi, Y. Maruyama, E. Riawan, and others (2010), Land subsidence characteristics of the Jakarta Basin (Indonesia) and its relation with groundwater extraction and sea level rise, Groundwater response to changing climate, IAH selected papers on hydrogeology, (16), 113-130.

Abidin, H. Z., H. Andreas, I. Gumilar, T. P. Sidiq, and M. Gamal (2015), Environmental impacts of land subsidence in urban areas of Indonesia, in FIG Working Week.

Ablain, M. et al. (2015), Improved sea level record over the satellite altimetry era (1993-2010) from the Climate Change Initiative project, Ocean Sci., 11(1), 67-82, doi:10.5194/os-11-67-2015.

Adelekan, I. O. (2009), Vulnerability of poor urban coastal communities to climate change in Lagos, Nigeria, in Fifth Urban research symposium, pp. 28-30.

Albert, S., J. X. Leon, A. R. Grinham, J. A. Church, B. R. Gibbes, and C. D. Woodroffe (2016), Interactions between sea-level rise and wave exposure on reef island dynamics in the Solomon Islands, Environmental Research Letters, 11(5), 054011.

Alothman, A. O., M. S. Bos, R. M. S. Fernandes, and M. E. Ayhan (2014), Sea level rise in the north-western part of the Arabian Gulf, Journal of Geodynamics, 81, 105-110.

Amin, A., and K. Bankher (1997), Causes of Land Subsidence in the Kingdom of Saudi Arabia, Natural Hazards, 16(1), 57-63, doi:10.1023/A:1007942021332.

Aparna, S. G., J. P. McCreary, D. Shankar, and P. N. Vinayachandran (2012), Signatures of Indian Ocean Dipole and El Niño-Southern Oscillation events in sea level variations in the Bay of Bengal, Journal of Geophysical Research: Oceans (1978-2012), 117(C10).

Arfanuzzaman, M., N. Mamnun, M. S. Islam, T. Dilshad, and M. A. Syed (2016), Evaluation of Adaptation Practices in the Agriculture Sector of Bangladesh: An Ecosystem Based Assessment, Climate, 4(1), 11.

Aubrey, D. G., K. O. Emery, and E. Uchupi (1988), Changing coastal levels of South America and the Caribbean region from tide-gauge records, Tectonophysics, 154(3), 269-284.

Ballu, V., M.-N. Bouin, P. Siméoni, W. C. Crawford, S. Calmant, J.-M. Boré, T. Kanas, and B. Pelletier (2011), Comparing the role of absolute sea-level rise and vertical tectonic motions in coastal flooding, Torres Islands (Vanuatu), Proceedings of the National Academy of Sciences, 108(32), 13019-13022.

Becker, M., B. Meyssignac, C. Letetrel, W. Llovel, A. Cazenave, and T. Delcroix (2012), Sea level variations at tropical Pacific islands since 1950, Global and Planetary Change, 80-81, 85-98, doi:10.1016/j.gloplacha.2011.09.004.

1108 Becker, M., M. Karpytchev, and S. Lennartz-Sassinek (2014), Long-term sea level trends: Natural or 
1110 Bellard, C., C. Leclerc, and F. Courchamp (2014), Impact of sea level rise on the 10 insular biodiversity hotspots,

1111 Global Ecology and Biogeography, 23(2), 203-212.

1112 Blum, M. D., and H. H. Roberts (2009), Drowning of the Mississippi Delta due to insufficient sediment supply and global sea-level rise, Nature Geoscience, 2(7), 488-491.

1114 Blum, M. D., and H. H. Roberts (2012), The Mississippi delta region: past, present, and future, Annual Review of Earth and Planetary Sciences, 40, 655-683.

Brammer, H. (2014), Bangladesh's dynamic coastal regions and sea-level rise, Climate Risk Management, 1, 5162, doi:10.1016/j.crm.2013.10.001.

1118 Brown, S., and R. J. Nicholls (2015), Subsidence and human influences in mega deltas: The case of the GangesBrahmaputra-Meghna, Science of The Total Environment, 527, 362-374.

Brown, S., Kebede, A. S., \& Nicholls, R. J. (2011). Sea-level rise and impacts in Africa, 2000 to 2100. School of

Civil Engineering and the Environment University of Southampton, UK. Retrieved from http://www.joyhecht.net/East Africa Climate Change/Brown et al Sea Level Rise.pdf

Buenfil-López, L. A., M. Rebollar-Plata, N. P. Muñoz-Sevilla, and B. Juárez-León (2012), Sea-Level Rise and Subsidence/Uplift Processes in the Mexican South Pacific Coast, Journal of Coastal Research, 1154-1164, doi:10.2112/JCOASTRES-D-11-00118.1.

Catalao, J., D. Raju, and R. M. S. Fernandes (2013), Mapping Vertical Land Movement In Singapore Using InSAR GPS, in ESA Special Publication, vol. 722, p. 54.

1128 Cazenave, A., and G. Le Cozannet (2013), Sea level rise and its coastal impacts, Earth's Future.

1129 Chaussard, E., F. Amelung, H. Abidin, and S.-H. Hong (2013), Sinking cities in Indonesia: ALOS PALSAR detects rapid subsidence due to groundwater and gas extraction, Remote Sensing of Environment, 128, 150-161.

Cheng, X., S.-P. Xie, Y. Du, J. Wang, X. Chen, and J. Wang (2016), Interannual-to-decadal variability and trends of sea level in the South China Sea, Clim Dyn, 46(9-10), 3113-3126, doi:10.1007/s00382-015-2756-1.

1133 Choudhury, A. M., M. A. Haque, and D. A. Quadir (1997), Consequences of global warming and sea level rise in 1134 Bangladesh, Marine Geodesy, 20(1), 13-31.

Church, J. A., N. J. White, R. Coleman, K. Lambeck, and J. X. Mitrovica (2004), Estimates of the regional distribution of sea level rise over the 1950-2000 period, Journal of climate, 17(13), 2609-2625.

Church, J. A., N. J. White, and J. R. Hunter (2006), Sea-level rise at tropical Pacific and Indian Ocean islands, Global and Planetary Change, 53(3), 155-168.

1139 Church, J. A. et al. (2013), Sea level change, Climate change, 1137-1216.

Clarke, A. J. (2014), El Niño physics and El Niño predictability, Annual review of marine science, 6, 79-99.

Clarke, A. J., and X. Liu (1994), Interannual Sea Level in the Northern and Eastern Indian Ocean, J. Phys. Oceanogr., 24(6), 1224-1235, doi:10.1175/1520-0485(1994)024<1224:ISLITN>2.0.CO;2.

Cohen, M. C., and R. J. Lara (2003), Temporal changes of mangrove vegetation boundaries in Amazonia: application of GIS and remote sensing techniques, Wetlands Ecology and Management, 11(4), 223-231. 1948 to 2004, J. Climate, 22(10), 2773-2792, doi:10.1175/2008JCLI2592.1.

Dasgupta, S., B. Laplante, C. Meisner, D. Wheeler, and J. Yan (2009), The impact of sea level rise on developing countries: a comparative analysis, Climatic change, 93(3-4), 379-388.

Deng, W., G. Wei, L. Xie, T. Ke, Z. Wang, T. Zeng, and Y. Liu (2013), Variations in the Pacific Decadal Oscillation since 1853 in a coral record from the northern South China Sea, Journal of Geophysical Research: Oceans, 118(5), 2358-2366.

1152 Ding, X., D. Zheng, Y. Chen, J. Chao, and Z. Li (2001), Sea level change in Hong Kong from tide gauge measurements of 1954-1999, Journal of Geodesy, 74(10), 683-689.

1154 Douglas, B. C. (2001), Sea level change in the era of the recording tide gauge, International Geophysics, 75, 37 115564.

1156 Ducarme, B., A. P. Venedikov, A. R. de Mesquita, C. A. de S. Franca, D. S. Costa, D. Blitzkow, R. V. Diaz, and 1157 S. R. C. de Freitas (2007), New analysis of a 50 years tide gauge record at Cananéia (SP-Brazil) with the VAV 
tidal analysis program, in Dynamic Planet, edited by D. P. Tregoning and D. C. Rizos, pp. 453-460, Springer 1159 Berlin Heidelberg.

1160 Duvat, V., A. Magnan, and F. Pouget (2013), Exposure of atoll population to coastal erosion and flooding: a South Tarawa assessment, Kiribati, Sustain Sci, 8(3), 423-440, doi:10.1007/s11625-013-0215-7.

Duvat, V. K. E., and V. Pillet (2017), Shoreline changes in reef islands of the Central Pacific: Takapoto Atoll, Northern Tuamotu, French Polynesia, Geomorphology, 282, 96-118, doi:10.1016/j.geomorph.2017.01.002.

Edelman, A. et al. (2014), State of the Tropics 2014 report, Report, James Cook University, Cairns.

Emery, K. O., and D. G. Aubrey (1986), Relative sea-level changes from tide-gauge records of eastern Asia mainland, Marine Geology, 72(1), 33-45.

1167 Emery, K. O., and D. G. Aubrey (1989), Tide gauges of India, Journal of Coastal Research, 489-501.

Emery, K. O., and D. G. Aubrey (1991), Sea levels, land levels, and tide gauges, Springer New York etc.

Enfield, D. B. (1989), El Niño, past and present, Reviews of Geophysics, 27(1), 159-187.

Erban, L. E., S. M. Gorelick, and H. A. Zebker (2014), Groundwater extraction, land subsidence, and sea-level rise in the Mekong Delta, Vietnam, Environ. Res. Lett., 9(8), 084010, doi:10.1088/1748-9326/9/8/084010.

Ericson, J. P., C. J. Vörösmarty, S. L. Dingman, L. G. Ward, and M. Meybeck (2006), Effective sea-level rise and deltas: causes of change and human dimension implications, Global and Planetary Change, 50(1), 63-82.

Fenoglio-Marc, L., T. Schöne, J. Illigner, M. Becker, P. Manurung, and Khafid (2012), Sea Level Change and Vertical Motion from Satellite Altimetry, Tide Gauges and GPS in the Indonesian Region, Marine Geodesy, $35(\sup 1), 137-150$.

Ferrier, K. L., J. X. Mitrovica, L. Giosan, and P. D. Clift (2015), Sea-level responses to erosion and deposition of sediment in the Indus River basin and the Arabian Sea, Earth and Planetary Science Letters, 416, 12-20.

Fiedler, J. W., and C. P. Conrad (2010), Spatial variability of sea level rise due to water impoundment behind dams, Geophysical Research Letters, 37(12).

França, M. C., M. I. Francisquini, M. C. Cohen, L. C. Pessenda, D. F. Rossetti, J. T. Guimaraes, and C. B. Smith (2012), The last mangroves of Marajó Island - Eastern Amazon: impact of climate and/or relative sea-level changes, Review of Palaeobotany and Palynology, 187, 50-65.

1184 French, G. T., L. F. Awosika, and C. E. Ibe (1995), Sea-level rise and Nigeria: potential impacts and consequences, 1185 Journal of Coastal Research, 224-242.

Fujihara, Y., K. Hoshikawa, H. Fujii, A. Kotera, T. Nagano, and S. Yokoyama (2015), Analysis and attribution of trends in water levels in the Vietnamese Mekong Delta, Hydrological Processes.

1188 Giosan, L., S. Constantinescu, P. D. Clift, A. R. Tabrez, M. Danish, and A. Inam (2006), Recent morphodynamics of the Indus delta shore and shelf, Continental Shelf Research, 26(14), 1668-1684, doi:10.1016/j.csr.2006.05.009.

Gratiot, N., E. J. Anthony, A. Gardel, C. Gaucherel, C. Proisy, and J. T. Wells (2008), Significant contribution of the 18.6 year tidal cycle to regional coastal changes, Nature Geoscience, 1(3), 169-172.

Guo, J., Z. Hu, J. Wang, X. Chang, and G. Li (2015), Sea level changes of China seas and neighboring ocean based on satellite altimetry missions from 1993 to 2012, Journal of Coastal Research, 73(sp1), 17-21.

Gupta, H., S.-J. Kao, and M. Dai (2012), The role of mega dams in reducing sediment fluxes: A case study of large Asian rivers, Journal of Hydrology, 464, 447-458.

Hallegatte, S., N. Ranger, O. Mestre, P. Dumas, J. Corfee-Morlot, C. Herweijer, and R. M. Wood (2011), Assessing climate change impacts, sea level rise and storm surge risk in port cities: a case study on Copenhagen, Climatic change, 104(1), 113-137.

1199 Hamlington, B. D., R. R. Leben, R. S. Nerem, W. Han, and K.-Y. Kim (2011), Reconstructing sea level using cyclostationary empirical orthogonal functions, J. Geophys. Res., 116(C12), C12015, doi:10.1029/2011JC007529.

Han, G., and W. Huang (2009), Low-frequency sea-level variability in the South China Sea and its relationship to ENSO, Theoretical and applied climatology, 97(1-2), 41-52.

Han, W. et al. (2010), Patterns of Indian Ocean sea-level change in a warming climate, Nature Geoscience, 3(8), $546-550$. 
Han, W., J. Vialard, M. J. McPhaden, T. Lee, Y. Masumoto, M. Feng, and W. P. De Ruijter (2014), Indian Ocean decadal variability: A review, Bulletin of the American Meteorological Society, 95(11), 1679-1703.

Hanson, S., R. Nicholls, N. Ranger, S. Hallegatte, J. Corfee-Morlot, C. Herweijer, and J. Chateau (2011), A global ranking of port cities with high exposure to climate extremes, Climatic Change, 104(1), 89-111, doi:10.1007/s10584-010-9977-4.

He, L., G. Li, K. Li, and Y. Shu (2014), Estimation of regional sea level change in the Pearl River Delta from tide gauge and satellite altimetry data, Estuarine, Coastal and Shelf Science, 141, 69-77.

Hedley, P. J., M. I. Bird, and R. A. Robinson (2010), Evolution of the Irrawaddy delta region since 1850, The Geographical Journal, 176(2), 138-149.

Higgins, S. A., I. Overeem, M. S. Steckler, J. P. Syvitski, L. Seeber, and S. H. Akhter (2014), InSAR measurements of compaction and subsidence in the Ganges-Brahmaputra Delta, Bangladesh, Journal of Geophysical Research: Earth Surface, 119(8), 1768-1781.

Hinkel, J., S. Brown, L. Exner, R. J. Nicholls, A. T. Vafeidis, and A. S. Kebede (2012), Sea-level rise impacts on Africa and the effects of mitigation and adaptation: an application of DIVA, Regional Environmental Change, 12(1), 207-224.

Holgate, S. J., A. Matthews, P. L. Woodworth, L. J. Rickards, M. E. Tamisiea, E. Bradshaw, P. R. Foden, K. M. Gordon, S. Jevrejeva, and J. Pugh (2013), New Data Systems and Products at the Permanent Service for Mean Sea Level, Journal of Coastal Research, 288, 493-504, doi:10.2112/JCOASTRES-D-12-00175.1.

Huq, S., S. I. Ali, and A. A. Rahman (1995), Sea-level rise and Bangladesh: a preliminary analysis, Journal of Coastal Research, 44-53.

Iftekhar, M. S., and P. Saenger (2008), Vegetation dynamics in the Bangladesh Sundarbans mangroves: a review of forest inventories, Wetlands Ecology and Management, 16(4), 291-312.

IPCC AR5 (2013), Climate Change 2013: The Physical Science Basis, Working Group I Contribution to the Fifth Assessment Report of the Intergovernmental Panel on Climate Change. Summary for Policymakers (IPCC, 2013).

Ivins, E. R., R. K. Dokka, and R. G. Blom (2007), Post-glacial sediment load and subsidence in coastal Louisiana, Geophysical Research Letters, 34(16).

Jallow, B. P., S. Toure, M. M. Barrow, and A. A. Mathieu (1999), Coastal zone of the Gambia and the Abidjan region in Côte d\$backslash\$'Ivoire: Sea level rise vulnerability, response strategies, and adaptation options, Climate Research, 12(2-3), 129-136.

Jurkowski, G., J. Ni, and L. Brown (1984), Modern uparching of the Gulf coastal plain, Journal of Geophysical Research: Solid Earth, 89(B7), 6247-6255.

Kench, P. S., R. F. McLean, R. W. Brander, S. L. Nichol, S. G. Smithers, M. R. Ford, K. E. Parnell, and M. Aslam (2006), Geological effects of tsunami on mid-ocean atoll islands: the Maldives before and after the Sumatran tsunami, Geology, 34(3), 177-180.

Kench, P. S., D. Thompson, M. R. Ford, H. Ogawa, and R. F. McLean (2015), Coral islands defy sea-level rise over the past century: Records from a central Pacific atoll, Geology, 43(6), 515-518.

Kesel, R. H. (2003), Human modifications to the sediment regime of the Lower Mississippi River flood plain, Geomorphology, 56(3), 325-334.

Khan, T. M. A., D. A. Quadir, T. S. Murty, A. Kabir, F. Aktar, and M. A. Sarker (2002), Relative sea level changes in Maldives and vulnerability of land due to abnormal coastal inundation, Marine Geodesy, 25(1-2), 133-143.

Kolker, A. S., M. A. Allison, and S. Hameed (2011), An evaluation of subsidence rates and sea-level variability in the northern Gulf of Mexico, Geophysical Research Letters, 38(21).

Kourtit, K., and P. Nijkamp (2013), In praise of megacities in a global world, Regional Science Policy \& Practice, 5(2), 167-182. Paleoenvironmental records, geophysical modelling, and reconstruction of sea level trends and variability on centennial and longer timescales, Wiley-Blackwell. 
level reconstructions: an example in French Polynesia, Journal of Coastal Research, 65.

Le Cozannet, G., D. Raucoules, G. Wöppelmann, M. Garcin, S. Da Sylva, B. Meyssignac, M. Gravelle, and F. Lavigne (2015), Vertical ground motion and historical sea-level records in Dakar (Senegal), Environmental Research Letters, 10(8), 084016.

Lee, H. S. (2013), Estimation of extreme sea levels along the Bangladesh coast due to storm surge and sea level rise using EEMD and EVA, J. Geophys. Res. Oceans, 118(9), 4273-4285, doi:10.1002/jgrc.20310.

Lemos, A. T., and R. D. Ghisolfi (2011), Long-term mean sea level measurements along the Brazilian coast: a preliminary assessment, Pan-Am J Aquat Sci, 5(2), 331-340.

Letetrel, C., M. Karpytchev, M.-N. Bouin, M. Marcos, A. SantamarÍla-Gómez, and G. Wöppelmann (2015), Estimation of vertical land movement rates along the coasts of the Gulf of Mexico over the past decades, Continental Shelf Research, 111, 42-51.

Llovel, W., A. Cazenave, P. Rogel, A. Lombard, and M. B. Nguyen (2009), Two-dimensional reconstruction of past sea level (1950-2003) from tide gauge data and an Ocean General Circulation Model, Clim. Past, 5(2), 217227, doi:10.5194/cp-5-217-2009.

Losada, I. J., B. G. Reguero, F. J. Méndez, S. Castanedo, A. J. Abascal, and R. Mínguez (2013), Long-term changes in sea-level components in Latin America and the Caribbean, Global and Planetary Change, 104, 34-50.

Loucks, C., S. Barber-Meyer, M. A. A. Hossain, A. Barlow, and R. M. Chowdhury (2010), Sea level rise and tigers: predicted impacts to Bangladesh's Sundarbans mangroves, Climatic Change, 98(1), 291-298.

Lovelock, C. E. et al. (2015), The vulnerability of Indo-Pacific mangrove forests to sea-level rise, Nature.

Mansur, A. V., E. S. Brondízio, S. Roy, S. Hetrick, N. D. Vogt, and A. Newton (2016), An assessment of urban vulnerability in the Amazon Delta and Estuary: a multi-criterion index of flood exposure, socio-economic conditions and infrastructure, Sustainability Science, 1-19.

McCann, W. R. (2006), Estimating the threat of tsunamogenic earthquakes and earthquake induced-landslide tsunami in the Caribbean, World Scientific Publishing, Singapore.

McGranahan, G., D. Balk, and B. Anderson (2007), The rising tide: assessing the risks of climate change and human settlements in low elevation coastal zones, Environment and urbanization, 19(1), 17-37.

McLean, R., and P. Kench (2015), Destruction or persistence of coral atoll islands in the face of 20th and 21st century sea-level rise?, Wiley Interdisciplinary Reviews: Climate Change, 6(5), 445-463.

Mcleod, E., J. Hinkel, A. T. Vafeidis, R. J. Nicholls, N. Harvey, and R. Salm (2010), Sea-level rise vulnerability in the countries of the Coral Triangle, Sustainability Science, 5(2), 207-222.

Mei-e, R. (1993), Relative sea-level changes in China over the last 80 years, Journal of Coastal Research, 229241.

Melet, A., R. Almar, and B. Meyssignac (2016), What dominates sea level at the coast: a case study for the Gulf of Guinea, Ocean Dynamics, 66(5), 623-636.

1288 Merrifield, M. A. (2011), A shift in western tropical Pacific sea level trends during the 1990s, Journal of Climate, 1289 24(15), 4126-4138.

Merrifield, M. A., P. R. Thompson, and M. Lander (2012), Multidecadal sea level anomalies and trends in the western tropical Pacific, Geophysical Research Letters, 39(13).

Mesquita, A. R. (2003), Sea-level variations along the Brazilian Coast: A short review, Journal of Coastal Research, 21-31.

Mesquita, A. R. de, A. dos S. Franco, J. Harari, and C. A. de S. França (2013), On sea level along the Brazillian coast, Revista Brasileira de Geofisica, 31(5), 33-42, doi:10.22564/rbgf.vol31n5-2013.

Meyssignac, B., M. Becker, W. Llovel, and A. Cazenave (2012a), An Assessment of Two-Dimensional Past Sea Level Reconstructions Over 1950-2009 Based on Tide-Gauge Data and Different Input Sea Level Grids, Surveys in Geophysics, 1-28.

Meyssignac, B., D. Salas y Melia, M. Becker, W. Llovel, and A. Cazenave (2012b), Tropical Pacific spatial trend patterns in observed sea level: internal variability and/or anthropogenic signature?, Climate of the Past, 8(2), 787802. 
Milliman, J., and B. U. Haq (1996), Sea-level rise and coastal subsidence: causes, consequences, and strategies,

Springer Science \& Business Media.

Milliman, J. D., J. M. Broadus, and F. Gable (1989), Environmental and economic implications of rising sea level and subsiding deltas: the Nile and Bengal examples, Ambio, 340-345.

Milly, P. C. D., A. Cazenave, J. S. Famiglietti, V. Gornitz, K. Laval, D. P. Lettenmaier, D. L. Sahagian, J. M. Wahr, and C. R. Wilson (2010), Terrestrial water-storage contributions to sea-level rise and variability, Understanding sea-level rise and variability, 226-255.

Milne, G. A., W. R. Gehrels, C. W. Hughes, and M. E. Tamisiea (2009), Identifying the causes of sea-level change, Nature Geosci, 2(7), 471-478, doi:10.1038/ngeo544.

1311 Mimura, N., L. Nurse, R. McLean, J. Agard, L. Briguglio, P. Lefale, R. Payet, and G. Sem (2007), Small islands, Climate change, 687-716.

Mitchum, G. T., and K. Wyrtki (1988), Overview of Pacific sea level variability, Marine Geodesy, 12(4), 235245.

Mitrovica, J. X., M. E. Tamisiea, J. L. Davis, and G. A. Milne (2001), Recent mass balance of polar ice sheets inferred from patterns of global sea-level change, Nature, 409(6823), 1026-1029.

Mittermeier, R. A., W. R. Turner, F. W. Larsen, T. M. Brooks, and C. Gascon (2011), Global biodiversity conservation: the critical role of hotspots, in Biodiversity hotspots, pp. 3-22, Springer.

Mochizuki, T., M. Kimoto, M. Watanabe, Y. Chikamoto, and M. Ishii (2016), Interbasin effects of the Indian Ocean on Pacific decadal climate change, Geophys. Res. Lett., 43(13), 2016GL069940, doi:10.1002/2016GL069940.

Moon, J.-H., Y. T. Song, and H. Lee (2015), PDO and ENSO modulations intensified decadal sea level variability in the tropical Pacific, Journal of Geophysical Research: Oceans, 120(12), 8229-8237.

Moriconi-Ebrard, F., D. Harre, and P. Heinrigs (2016), Urbanisation Dynamics in West Africa 1950-2010, Organisation for Economic Co-operation and Development, Paris.

Morton, R. A., J. C. Bernier, and J. A. Barras (2006), Evidence of regional subsidence and associated interior wetland loss induced by hydrocarbon production, Gulf Coast region, USA, Environmental Geology, 50(2), 261274.

Muehe, D. (2006), Erosion in the Brazilian coastal zone: an overview, Journal of Coastal Research, 43-48.

Muehe, D. (2010), Brazilian coastal vulnerability to climate change, Pan-American Journal of Aquatic Sciences, $5(2), 173-183$.

Muehe, D., and C. F. Neves (1995), The implications of sea-level rise on the Brazilian coast: a preliminary assessment, Journal of Coastal Research, 54-78.

Mundial, B. (2014), World Development Indicators 2014, Relaciones Internacionales.

Nali, J. O., and D. Rigo (2011), Urban floods: assessing the effects of sea level rise and mitigation measures, Porto Alegre/Brazil.

Nandy, S., and S. Bandopadhyay (2011), Trend of sea level change in the Hugli estuary, India, Indian Journal of Geo-Marine Sciences, 40(6), 802-812.

Neves, C. F., and D. Muehe (1995), Potential impacts of sea-level rise on the Metropolitan Region of Recife, Brazil, Journal of Coastal Research, 116-131.

1341 Nicholls, R. J., and A. Cazenave (2010), Sea-level rise and its impact on coastal zones, science, 328(5985), 151713421520

1343 Nicholls, R. J., and N. Mimura (1998), Regional issues raised by sea-level rise and their policy implications, Climate research, 11(1), 5-18.

Nicholls, R. J., F. M. Hoozemans, and M. Marchand (1999), Increasing flood risk and wetland losses due to global sea-level rise: regional and global analyses, Global Environmental Change, 9, S69-S87. 
$161-181$

Nieves, V., J. K. Willis, and W. C. Patzert (2015), Recent hiatus caused by decadal shift in Indo-Pacific heating, Science, 349(6247), 532-535.

Nurse, L. A., R. F. MCLEAN, J. AGARD, L. P. BRIGUGLIO, V. DUVAT-MAGNAN, N. PELESIKOTI, E. TOMPKINS, and A. WEBB (2014), Small islands, in Climate Change 2014: Impacts, Adaptation, and Vulnerability. Part B: Regional Aspects. Contribution of Working Group II to the Fifth Assessment Report of the Intergovernmental Panel on Climate Change., p. pp-1613, [Barros, V.R., C.B. Field, D.J. Dokken, M.D. Mastrandrea, K.J. Mach, T.E. Bilir, M. Chatterjee, K.L. Ebi, Y.O. Estrada, R.C. Genova, B. Girma, E.S. Kissel, A.N. Levy, S. MacCracken, P.R. Mastrandrea, and L.L. White (eds.)] -Cambridge University Press.

1356
Overeem, I., and J. P. M. Syvitski (2009), Dynamics and vulnerability of delta systems, GKSS Research Centre, LOICZ Internat. Project Office, Inst. for Coastal Research.

Palanisamy, H., M. Becker, B. Meyssignac, O. Henry, and A. Cazenave (2012), Regional sea level change and variability in the Caribbean sea since 1950, Journal of Geodetic Science, 2(2), 125-133.

Palanisamy, H., A. Cazenave, B. Meyssignac, L. Soudarin, G. Wöppelmann, and M. Becker (2014), Regional sea level variability, total relative sea level rise and its impacts on islands and coastal zones of Indian Ocean over the last sixty years, Global and Planetary Change, 116, 54-67, doi:10.1016/j.gloplacha.2014.02.001.

Palanisamy, H., A. Cazenave, T. Delcroix, and B. Meyssignac (2015), Spatial trend patterns in the Pacific Ocean sea level during the altimetry era: the contribution of thermocline depth change and internal climate variability, Ocean Dynamics, 65(3), 341-356.

Payo Garcia, A. et al. (2016), Projected changes in area of the Sundarban mangrove forest in Bangladesh due to SLR by 2100, Climatic Change, 139(2), 279-291, doi:P10.1007/s10584-016-1769-z.

Peltier, W. R. (2004), Global glacial isostasy and the surface of the ice-age Earth: the ICE-5G (VM2) model and GRACE, Annu. Rev. Earth Planet. Sci., 32, 111-149.

Peng, D., H. Palanisamy, A. Cazenave, and B. Meyssignac (2013), Interannual sea level variations in the South China Sea over 1950-2009, Marine Geodesy, 36(2), 164-182.

Perez, R. T., L. A. Amadore, and R. B. Feir (1999), Climate change impacts and responses in the Philippines coastal sector, Climate Research, 12(2-3), 97-107.

Pethick, J., and J. D. Orford (2013), Rapid rise in effective sea-level in southwest Bangladesh: Its causes and contemporary rates, Global and Planetary Change, 111, 237-245, doi:10.1016/j.gloplacha.2013.09.019.

Phien-wej, N., P. H. Giao, and P. Nutalaya (2006), Land subsidence in Bangkok, Thailand, Engineering Geology, 82(4), 187-201, doi:10.1016/j.enggeo.2005.10.004.

Piecuch, C. G., and R. M. Ponte (2015), Inverted barometer contributions to recent sea level changes along the northeast coast of North America, Geophysical Research Letters, 42(14), 5918-5925.

Ponte, R. M. (1994), Understanding the relation between wind-and pressure-driven sea level variability, Journal of Geophysical Research: Oceans, 99(C4), 8033-8039.

Pugh, D., and P. Woodworth (2014), Sea-level science: understanding tides, surges, tsunamis and mean sea-level changes, Cambridge University Press.

Rahman, A. F., D. Dragoni, and B. El-Masri (2011), Response of the Sundarbans coastline to sea level rise and decreased sediment flow: A remote sensing assessment, Remote Sensing of Environment, 115(12), 3121-3128, doi:10.1016/j.rse.2011.06.019.

Rao, K. N., P. Subraelu, T. V. Rao, B. H. Malini, R. Ratheesh, S. Bhattacharya, A. S. Rajawat, and others (2008), Sea-level rise and coastal vulnerability: an assessment of Andhra Pradesh coast, India through remote sensing and GIS, Journal of Coastal Conservation, 12(4), 195-207.

Raucoules, D., G. Le Cozannet, G. Wöppelmann, M. De Michele, M. Gravelle, A. Daag, and M. Marcos (2013), High nonlinear urban ground motion in Manila (Philippines) from 1993 to 2010 observed by DInSAR: Implications for sea-level measurement, Remote Sensing of Environment, 139, 386-397.

Ray, R. D., and B. C. Douglas (2011), Experiments in reconstructing twentieth-century sea levels, Progress in Oceanography, 91(4), 496-515, doi:10.1016/j.pocean.2011.07.021.

Reguero, B. G., I. J. Losada, P. Díaz-Simal, F. J. Méndez, and M. W. Beck (2015), Effects of Climate Change on 
Exposure to Coastal Flooding in Latin America and the Caribbean, PLOS ONE, 10(7), e0133409, 1400 doi:10.1371/journal.pone.0133409.

1401 Riva, R. E., J. L. Bamber, D. A. Lavallée, and B. Wouters (2010), Sea-level fingerprint of continental water and ice mass change from GRACE, Geophysical Research Letters, 37(19).

1403 Roden, G. I. (1963), Sea level variations at Panama, Journal of Geophysical Research, 68(20), 5701-5710.

1404

1405

1406

1407

1408

1409

1410

1411

1412

1413

1414

1415

1416

1417

1418

1419

1420

1421

1422

1423

1424

1425

1426

1427

1428

1429

1430

1431

1432

1433

1434

1435

1436

1437

1438

1439

1440

1441

1442

1443

1444

1445

1446

Rodolfo, K. S., and F. P. Siringan (2006), Global sea-level rise is recognised, but flooding from anthropogenic land subsidence is ignored around northern Manila Bay, Philippines, Disasters, 30(1), 118-139.

Rong, Z., Y. Liu, H. Zong, and Y. Cheng (2007), Interannual sea level variability in the South China Sea and its response to ENSO, Global and Planetary Change, 55(4), 257-272.

Ruane, A. C. et al. (2013), Multi-factor impact analysis of agricultural production in Bangladesh with climate change, Global Environmental Change, 23(1), 338-350.

Saglio-Yatzimirsky, M.-C. (2013), Megacity slums: social exclusion, space and urban policies in Brazil and India, World Scientific.

Sallenger, A. H., Doran, K. S., \& Howd, P. A. (2012). Hotspot of accelerated sea-level rise on the Atlantic coast of North America. Nature Climate Change, 2(12), 884-888.

Santamaría-Gómez, A., Gravelle, M., Dangendorf, S., Marcos, M., Spada, G., \& Wöppelmann, G. (2017). Uncertainty of the 20th century sea-level rise due to vertical land motion errors. Earth and Planetary Science Letters, 473, 24-32.

Saramul, S., and T. Ezer (2014), Spatial variations of sea level along the coast of Thailand: Impacts of extreme land subsidence, earthquakes and the seasonal monsoon, Global and Planetary Change, 122, 70-81.

Sarwar, M. G. M. (2013), Sea-Level Rise Along the Coast of Bangladesh, in Disaster Risk Reduction Approaches in Bangladesh, pp. 217-231, Springer.

Sarwar, M. G. M., and C. D. Woodroffe (2013), Rates of shoreline change along the coast of Bangladesh, J Coast Conserv, 17(3), 515-526, doi:10.1007/s11852-013-0251-6.

Shankar, D., and S. R. Shetye (1999), Are interdecadal sea level changes along the Indian coast influenced by variability of monsoon rainfall?, Journal of Geophysical Research: Oceans (1978-2012), 104(C11), 2603126042.

Shankar, D., S. G. Aparna, J. P. McCreary, I. Suresh, S. Neetu, F. Durand, S. S. C. Shenoi, and M. A. Al Saafani (2010), Minima of interannual sea-level variability in the Indian Ocean, Progress in Oceanography, 84(3-4), 225241, doi:10.1016/j.pocean.2009.10.002.

Shearman, P., J. Bryan, and J. P. Walsh (2013), Trends in Deltaic Change over Three Decades in the Asia-Pacific Region, Journal of Coastal Research, 290, 1169-1183, doi:10.2112/JCOASTRES-D-12-00120.1.

Short, A. D., and A. H. da F. Klein (2016), Brazilian Beach Systems: Review and Overview, in Brazilian Beach Systems, pp. 573-608, Springer.

Singh, O. P. (2002), Predictability of sea level in the Meghna estuary of Bangladesh, Global and Planetary Change, 32(2-3), 245-251, doi:10.1016/S0921-8181(01)00152-7.

Singh, R. B. (2014), Urban Development Challenges, Risks and Resilience in Asian Mega Cities, Springer.

Sinha, P. C., Y. R. Rao, S. K. Dube, and T. S. Murty (1997), Effect of sea level rise on tidal circulation in the Hooghly Estuary, Bay of Bengal, Marine Geodesy, 20(4), 341-366, doi:10.1080/01490419709388114.

Soumya, M., P. Vethamony, and P. Tkalich (2015), Inter-annual sea level variability in the southern South China Sea, Global and Planetary Change, 133, 17-26.

Stammer, D. (2008), Response of the global ocean to Greenland and Antarctic ice melting, Journal of Geophysical Research: Oceans, 113(C6).

Stammer, D., A. Cazenave, R. M. Ponte, and M. E. Tamisiea (2013), Causes for contemporary regional sea level changes, Annual review of marine science, 5, 21-46.

Strassburg, M. W., B. D. Hamlington, R. R. Manrung, J. Lumban-Gaol, B. Nababan, and K.-Y. Kim (2015), Sea level trends in Southeast Asian seas, Climate of the Past, 11(5).

Suresh, I., J. Vialard, M. Lengaigne, W. Han, J. McCreary, F. Durand, and P. M. Muraleedharan (2013), Origins 
of wind-driven intraseasonal sea level variations in the North Indian Ocean coastal waveguide, Geophys. Res.

Lett., 40(21), 2013GL058312, doi:10.1002/2013GL058312.

1449 Suresh, I., J. Vialard, T. Izumo, M. Lengaigne, W. Han, J. McCreary, and P. M. Muraleedharan (2016), Dominant role of winds near Sri Lanka in driving seasonal sea level variations along the west coast of India, Geophysical Research Letters, 43(13), 7028-7035.

1452 Syvitski, J. P. (2008), Deltas at risk, Sustainability Science, 3(1), 23-32.

Syvitski, J. P., and A. Kettner (2011), Sediment flux and the Anthropocene, Philosophical Transactions of the Royal Society of London A: Mathematical, Physical and Engineering Sciences, 369(1938), 957-975.

Syvitski, J. P., A. J. Kettner, I. Overeem, E. W. Hutton, M. T. Hannon, G. R. Brakenridge, J. Day, C. Vörösmarty, Y. Saito, and L. Giosan (2009), Sinking deltas due to human activities, Nature Geoscience, 2(10), 681-686.

Syvitski, J. P., A. J. Kettner, I. Overeem, L. Giosan, G. R. Brakenridge, M. Hannon, and R. Bilham (2013), Anthropocene metamorphosis of the Indus Delta and lower floodplain, Anthropocene, 3, 24-35.

Tamisiea, M. E. (2011), Ongoing glacial isostatic contributions to observations of sea level change, Geophysical Journal International, 186(3), 1036-1044.

Tamisiea, M. E., and J. X. Mitrovica (2011), The moving boundaries of sea level change: Understanding the origins of geographic variability, Oceanography.

Thompson, P. R., C. G. Piecuch, M. A. Merrifield, J. P. McCreary, and E. Firing (2016), Forcing of recent decadal variability in the Equatorial and North Indian Ocean, Journal of Geophysical Research: Oceans, 121(9), 67626778 .

Tkalich, P., P. Vethamony, Q.-H. Luu, and M. T. Babu (2013), Sea level trend and variability in the Singapore Strait,

Törnqvist, T. E., D. J. Wallace, J. E. Storms, J. Wallinga, R. L. Van Dam, M. Blaauw, M. S. Derksen, C. J. Klerks, C. Meijneken, and E. M. Snijders (2008), Mississippi Delta subsidence primarily caused by compaction of Holocene strata, Nature Geoscience, 1(3), 173-176.

Torres, R. R., and M. N. Tsimplis (2013), Sea-level trends and interannual variability in the Caribbean Sea, Journal of Geophysical Research: Oceans, 118(6), 2934-2947.

Trisirisatayawong, I., M. Naeije, W. Simons, and L. Fenoglio-Marc (2011), Sea level change in the Gulf of Thailand from GPS-corrected tide gauge data and multi-satellite altimetry, Global and Planetary Change, 76(3), $137-151$.

Tseng, Y.-H., L. C. Breaker, and E. T.-Y. Chang (2010), Sea level variations in the regional seas around Taiwan, Journal of oceanography, 66(1), 27-39.

UN-HABITAT (2014), State of African Cities 2014, Re-imagining sustainable urban transitions, State of Cities -

1480 Unnikrishnan, A. S., and D. Shankar (2007), Are sea-level-rise trends along the coasts of the north Indian Ocean consistent with global estimates?, Global and Planetary Change, 57(3), 301-307.

1482 Veit, E., and C. P. Conrad (2016), The impact of groundwater depletion on spatial variations in sea level change during the past century, Geophysical Research Letters, 43(7), 3351-3359.

Wada, Y., L. P. Beek, F. C. Sperna Weiland, B. F. Chao, Y.-H. Wu, and M. F. Bierkens (2012), Past and future contribution of global groundwater depletion to sea-level rise, Geophysical Research Letters, 39(9). pumped from underground and contributions to sea-level rise, Nature Climate Change, 6(8), 777-780.

1488 Warrick, R. A., and Q. K. Ahmad (2012), The implications of climate and sea-level change for Bangladesh, 1489 Springer Science \& Business Media.

Webb, A. P., and P. S. Kench (2010), The dynamic response of reef islands to sea-level rise: Evidence from multidecadal analysis of island change in the Central Pacific, Global and Planetary Change, 72(3), 234-246.

Wilson, C. A., and S. L. Goodbred (2015), Construction and Maintenance of the Ganges-Brahmaputra-Meghna Delta: Linking Process, Morphology, and Stratigraphy, http://dx.doi.org/10.1146/annurev-marine-010213135032. Available from: http://www.annualreviews.org/doi/10.1146/annurev-marine-010213-135032 (Accessed 1 February 2017) 
Preprint of: Becker, M., Karpytchev, M., \& Papa, F. (2018). Hotspots of relative sea level rise in the Tropics. In Tropical Extremes: Natural Variability and Trends (pp. 203-251). Elsevier. Retrieved from www.elsevier.com/books/tropical-extremes-natural-

variability-and-trends/vuruputur/978-0-12-809248-4

Wilson, S. G., and T. R. Fischetti (2010), Coastline population trends in the United States: 1960 to 2008, US Department of Commerce, Economics and Statistics Administration, US Census Bureau.

1498 Wolanski, E. (2006), The environment in Asia Pacific harbours, Springer.

1499 Wolstencroft, M., Z. Shen, T. E. Törnqvist, G. A. Milne, and M. Kulp (2014), Understanding subsidence in the 1500 Mississippi Delta region due to sediment, ice, and ocean loading: Insights from geophysical modeling, J. Geophys. 1501 Res. Solid Earth, 119(4), 2013JB010928, doi:10.1002/2013JB010928.

1502 Woodworth, P. L. (2005), Have there been large recent sea level changes in the Maldive Islands?, Global and 1503 Planetary Change, 49(1), 1-18.

1504 Woodworth, P. L., A. Aman, and T. Aarup (2007), Sea level monitoring in Africa, African Journal of Marine 1505 Science, 29(3), 321-330.

1506 Wöppelmann, G., and M. Marcos (2016), Vertical land motion as a key to understanding sea level change and variability, Rev. Geophys., 54(1), 2015RG000502, doi:10.1002/2015RG000502.

1508 Wöppelmann, G., B. M. Miguez, M.-N. Bouin, and Z. Altamimi (2007), Geocentric sea-level trend estimates from GPS analyses at relevant tide gauges world-wide, Global and Planetary Change, 57(3), 396-406.

Wöppelmann, G., B. M. Míguez, and R. Créach (2008), Tide gauge records at Dakar, Senegal (Africa): towards a 100-years consistent sea-level time series?, European Geosciences Union, General Assembly 2008 (Vienna, Austria, 13-18th April 2008).

$1513 \mathrm{Wu}, \mathrm{T}$. W. et al. (2014), An overview of BCC climate system model development and application for climate change studies, Acta Meteorol Sin, 28(1), 34-56, doi:10.1007/s13351-014-3041-7.

1515 Wunsch, C., and D. Stammer (1997), Atmospheric loading and the oceanic "inverted barometer" effect, Reviews 1516 of Geophysics, 35(1), 79-107.

1517 Wyrtki, K. (1973), Teleconnections in the equatorial Pacific Ocean, Science, 180(4081), 66-68.

1518 Wyrtki, K. (1975), El Niño - the dynamic response of the equatorial Pacific Oceanto atmospheric forcing, Journal 1519 of Physical Oceanography, 5(4), 572-584.

1520 Yanagi, T., and T. Akaki (1994), Sea level variation in the Eastern Asia, Journal of Oceanography, 50(6), 6431521651. 